\title{
Um relance histórico sobre a Junta de Justiça de Angra, bosquejo de história judiciária liberal ${ }^{1}$
}

\section{A Historical Account about the Board of Justice of Angra, Sketch of the Liberal Judicial History}

\author{
Isabel GRAES \\ Professora auxiliar \\ Faculdade de Direito \\ Universidade de Lisboa \\ Isabel.Graes@tcontas.pt
}

Recibido: 1 de junio de 2011

Aceptado: 25 de julio de 2011

\begin{abstract}
RESUMEN
Dentro del Archivo de la Torre do Tombo se encuentra un manuscrito que resalta factores hasta ahora desconocidos de la historia judicial portuguesa, relativa al periodo comprendido entre 1830-1832. Dicho documento recoge entre sus inmumerables folios, que se semeja a un libro de registo, los trámites procesales criminales, estableciendo un tribunal de instrucción judicial al inicio del Ochocientos, enriquecido con las nuevas ideas doctrinales; se analizará también la tradición judicial en los albores del liberalismo portugués.
\end{abstract}

PALABRAS CLAVE: Procedimiento, liberalismo portugués, Junta de justicia de Angra, proceso penal, Arquivio da Torre do Tombo.

\begin{abstract}
The Torre do Tombo's Archive preserves a manuscript that highlights factors now unknown of the Portuguese judicial history, concerning the period between 1830-1832. This document, that resembles a registration book, includes among its myriad folios the criminal procedures. At the beginning of the $19^{\text {th }}$ century a Court of judicial proceedings was established, enriched with new doctrinal ideas. We will analyze also the judicial tradition on the eve of the Portuguese liberalism.
\end{abstract}

KEYWORDS: Procedure, Portuguese liberalism, Angra's Board of Justice, Criminal proceedings, Archive da Torre do Tombo.

\section{RÉSUMÉ}

Dans les Archives de la Torre do Tombo se trouverait un manuscrit qui met en lumière des facteurs maintenant inconnus de l'histoire judiciaire portugaise, concernant la période allant de 1830-1832. Ce

${ }^{1}$ O presente texto foi apresentado na sessão de 1 de Junho de 2011 das II Jornadas Científicas HispanoPortuguesas de Historia del Derecho (Historia de la administración de justicia en España y Portugal), realizadas na Faculdade de Direito da Universidade Complutense de Madrid. 
document, qui ressemble à un registre d'immatriculation, inclut parmi ses innombrables folios des procédures criminels instituant un tribunal de la procédure judiciaire au début du XIX $\mathrm{X}^{\mathrm{e}}$ siècle, enrichi avec de nouvelles idées doctrinales. On analysera également la tradition judiciaire à la veille du libéralisme portugaise.

MOTS CLÉ : Procédure, libéralisme portugaise, Conseil de la Justice d'Angra, procédures pénales, Archives da Torre do Tombo.

\section{ZUSAMMENFASSUNG}

Im Archiv von la Torre do Tombo findet sich ein Manuskript, aus dem bislang in der portugiesischen Rechtsgeschichte für die Zeit von 1830-1832 unbekannte Fakten sprießen. Die einem Registerbuch gleichende Quelle beinhaltet auf ihren zahlreichen Seiten Strafprozess-Formalitäten, die ein Instruktionsgericht zu Beginn des 18. Jahrhunderts erfüllen musste. Hinzu treten neue Strafrechtslehren, die Spuren des portugiesischen Liberalismus ankündigen.

SCHLÜSSELWÖRTER: Verfahrensgang, portugiesischer Liberalismus, Gerichtsversammlung von Angra, Strafprozess, Archiv "Torre do Tombo".

SUMARIO: 1. Apresentação. 2. Introdução. 3. O traçado geo-judiciário no alvor do liberalismo português. 4. A Junta de Justiça. a. Do projecto efémero da Relação de Angra à criação da Junta de Justiça. b. Localização e sede. c. Natureza jurídica deste tribunal. d. Competência. e. Continuação. f. Composição. g. O presidente da Junta de Justiça. h. O escrivão. i. O Procurador da Coroa. j. Os advogados junto da Junta de Justiça. k. Dissolução (O Decreto de 20 de Maio de 1832). 5. Conclusão.

\section{Apresentação}

Enredados em pesquisas documentais no Arquivo da Torre do Tombo, deparámos com a existência de um documento manuscrito que, quase de modo imperceptível, relata em tom documental alguns dos factos que compuseram a história judiciária oitocentista verificada no período de $1830-1832$, na ilha Terceira.

O presente documento pode ser equiparado a um livro de porta, ou seja a um livro de registo de processos em trâmite e de todos os actos decorrentes destes últimos, assim como da correspondência recebida e enviada, sendo composto por um único volume manuscrito, o qual integrou o acervo arquivístico do tribunal da Relação de Angra. Os documentos que nele se encontram trasladados, e que citaremos em nota de rodapé, dizem respeito a textos legislativos, sumários de alguns processos, termos de juramento e posse de magistrados e funcionários judiciais. Nele se encontra disposto, por ordem cronológica, um conjunto de quatro dezenas de documentos relativo ao Conselho de Justiça ou Supremo Conselho Militar (criado em Angra em 1829) e à Junta de Justiça (1830-1832). Apenas sobre esta última entidade recairá a nossa análise, com a qual pretendemos evidenciar os aspectos que distinguiram este tribunal na construção do aparelho judiciário do início de oitocentos, ainda que o mesmo tenha sido esquecido pela doutrina coeva. 
O Portugal histórico, a nação que vivera da Índia, depois do Brasil, ninho de mercadores e soldados, escritório de uma vasta fazenda ultramarina, acabava por uma vez, para todo o sempre. ${ }^{2}$

\section{Introdução}

As palavras com que iniciámos o presente bosquejo histórico parecem carreadas de algum cepticismo ou tomadas pela desilusão contagiante de Oliveira Martins. No entanto, não podemos ignorar que a revolução que era prometida em 1820 esteve longe de atingir os seus objectivos mais imediatos ${ }^{3}$. Antes e depois de 1831-4, a história do liberalismo é uma comédia de mau gosto, afirma Herculano ${ }^{4}$. Ferozmente influenciada nos seus primórdios pelo exemplo jacobino, cedo o quadro judiciário se revelaria primorosamente lusitano, pejado de vários subperíodos que conduziriam as vozes mais desiludidas com o constitucionalismo que se implementou, a criticar negativamente, e não sem razão, o regime que se foi consolidando. Os fins que se procuravam realizar e os modelos que se iam implementando reflectiam, na sua maioria, necessidades locais e ambições pessoais. Sob o espírito revolucionário, algumas alterações foram introduzidas no início da década que assistira à imposição de retorno da Corte a uma metrópole já esquecida, mas a caracterizá-las revelava-se igualmente uma arrogância impotente.

Em 1826, D. João VI deixava, pela segunda vez, o Reino votado à orfandade. As súbitas decisões de D. Pedro, então imperador do Brasil, a favor de sua filha Maria da Glória, outorgando, ao mesmo tempo e de modo apressado, um texto constitucional de contornos inquestionavelmente conservadores ainda que parecesse querer continuar a política conciliatória de seu pai, acaba por conduzir ao trono, seu irmão D. Miguel, que ao invés de regente é aclamado como legítimo herdeiro e soberano (Julho de 1828). Ainda que o período de 1826 a 1828 tenha assistido a algumas convulsões políticas, com especial relevo para a ocorrência de algumas sedições militares que rapidamente seriam sufocadas, será durante os seis anos da dramática e acintosa governação de D. Miguel que a reaç̧ão por parte da oposição liberal se tornará efectiva.

Neste palco de guerra, se destacará a ilha Terceira, a qual permanecerá como baluarte do liberalismo no período de 1829-1832. Nela será organizado um governo provisório, composto por um número considerável de exilados e de locais, sob a regência do Pedro de Sousa Holstein, $1^{\circ}$ marquês de Palmela 5 . Em Março de 1832, D.

\footnotetext{
${ }^{2}$ J.P. de Oliveira Martins, História de Portugal, INCM, s/1, 1988, p. 286.

${ }^{3}$ Inúmeras são as passagens que poderíamos aqui citar. Em tom de síntese, recorremos, mais uma vez, às ímpares palavras de Oliveira Martins para quem a revolução era, em si própria, um episódio da mais lenta decomposição, in op. cit., p. 256.

${ }^{4}$ In Oliveira Martins, op. cit., p. 287.

${ }^{5}$ Ainda acerca do governo interino formado em Angra, e de acordo com o relato constante nos Anais da Ilha Terceira (doc. Q.), dele terá feito parte João José da Cunha Ferraz, José Rodrigo de Almeida e Manuel Joaquim Nogueira em virtude da escusa do corregedor Francisco José Pacheco. Eram ajudantes de
} 
Pedro, então chegado a Angra, substituiria Palmela na Regência, partindo, em seguida, com destino ao Mindelo.

\section{O traçado geo-judiciário no alvor do liberalismo português}

1. Os anos de 1829 e 1830 marcam um dos períodos de destaque político da ilha Terceira, especialmente enquanto expoente de manifestações liberais por oposição ao domínio absolutista que se fazia sentir no continente do reino sobretudo desde Abril do ano anterior, ainda que a aclamação de D. Miguel também se tenha feito ouvir nos Açores (18 de Maio de 1828). O culminar desta revolta liberal atingiria o seu vértice com a chegada de Palmela à Terceira e a constituição da Regência (15 de Março de 1830). No ano seguinte, a ocupação liberal estender-se-ia às demais ilhas do arquipélago levando D. Pedro a instalar-se em São Miguel depois de uma curta estadia em França.

Portugal vivia não na revolução, mas a revolução. Se politicamente o cenário é de instabilidade, em termos judiciários, a realidade não é muito distinta. Instalada a Regência em 1829, a criação da Junta de Justiça ocorrida no ano seguinte resultaria como uma das primeiras decisões daquele governo. Importa recordar que a opção em sediar este tribunal em Angra não obedeceria a qualquer plano prévio de geografia

ordens do mesmo executivo, Teotónio de Ornelas Bruges Ávila e Manuel Homem da Costa Noronha. Sobre a formação do governo na Ilha Terceira, cfr. Drummond, Francisco Ferreira, Anais da Ilha Terceira, reimpressão fac-similada da edição de 1850, Secretaria Regional da Educação e Cultura, 1981.

Vd. Oliveira Marques, A. H., de, História de Portugal, vol. III, Palas Editores, Lisboa, 1981; Mattoso, José, História de Portugal, vols. 4, 5 e 6, Estampa, Lisboa, 1998; Peres, Damião, Cerdeira, Eleutério, História de Portugal, edição monumental comemorativa do oitavo centenário da fundação da nacionalidade, profusamente ilustrada e colaborada pelos mais eminentes historiadores e artistas portugueses, Portucalense Editora Limitada, Barcelos, 1929 e 1931; Saraiva, José Hermano, História de Portugal, sob a direcção de José Hermano Saraiva, Publicações Alfa, Lisboa, 1983; Schaeffer, Henrique, História de Portugal, desde a fundação da monarchia até à Revolução de 1820, vertida fiel, integrada e directamente, continuada, sob o mesmo plano, até aos nossos dias por J. Pereira de Sampaio (Bruno), Escriptorio da Empreza Editora, Porto, 1895; Serrão, Joaquim Veríssimo, Dicionário de História de Portugal, Iniciativas Editoriais, Lisboa, 1963; Serrão, Joel e Oliveira Marques, A.H. de, Nova História de Portugal, Portugal e a instauração do liberalismo, vol. IX, Editorial Presença, Lisboa, 2002; Dicionário de História de Portugal, sob direcção de Joel Serrão, Livraria Figueirinhas, Porto, 1992.

Pedro de Sousa HOLSTEIN (Turim, 1781-Lisboa, 1850), $1^{\circ}$ conde, $1^{\circ}$ marquês e $1^{\circ}$ duque de Palmela e conde de Sanfré. Filho primogénito do primeiro casamento de D. Alexandre de Sousa Holstein e de D. Isabel Juliana de Sousa. Segue a carreira diplomática tendo estado presente no Congresso de Viena (1815), é nomeado Secretário de Estado dos Negócios Estrangeiros (1817 e 1823), presidente da Junta preparatória da Carta Constitucional, presidente do Conselho de Ministros (1834-35, 1846), ministro dos Negócios Estrangeiros (1835), do Reino (1846), da Fazenda (1846), par do Reino (1836), Câmara de que foi eleito presidente (1842), tendo, igualmente, sido presidente do tribunal de justiça da Câmara dos Pares para deliberar sobre o processo de Joaquim Pedro Celestino Soares, senador (184942), presidente desta mesma assembleia política (1840-1841); presidiu ao governo do Entrudo. Integrou, ainda, várias comissões de Legislação. 
judiciária, mas apenas um conjunto de circunstâncias políticas que o tornavam imperativamente necessário.

As dificuldades apresentadas pelo mapa judiciário eram notórias, até porque o vintismo procurava proceder à transposição e adaptação da legislação dos finais de setencentos. Assim, a Lei de 20 de Agosto de 1774, alterada pelos diplomas de 19 de Julho de 1790 e de 20 de Agosto de 1792, dividia o reino em dois distritos judiciais, o primeiro correspondendo à área de jurisdição da Casa da Suplicação, com sede em Lisboa e que era constituído pelas províncias da Estremadura, Alentejo, Algarve, comarca de Castelo Branco, ilhas adjacentes, províncias de Cabo Verde, S. Tomé e Príncipe e África Ocidental (OF, 1.6.12); e o segundo, relativamente à Casa do Cível, com sede no Porto, o qual era composto pelas províncias de Trás-os-Montes, Entre-Douro e Minho e Beira. Cada distrito encontrava-se dividido em comarcas (da competência de um corregedor que tinha atribuições criminais e cíveis), que por sua vez se subdividiam em termos e, estes, em vintenas. Assim se encontravam delineados cerca de novecentos concelhos e coutos, donde apenas se pode salientar, face aos primeiros, um total de duzentos e trinta e cinco concelhos com juízes de fora de vara branca.

No reino era mantida, em paralelo, a jurisdição dos donatários, ainda que alguns diplomas setecentistas tivessem, em teoria, posto cobro a tal situação. De igual modo, não podem ser esquecidas as casas do Infantado, e Bragança, das Rainhas, da Ordem de Malta, da Universidade e um número deveras elevado de conservatórias estrangeiras que continuavam a exercer a sua própria jurisdição.

Importa, igualmente, não esquecer que as funções judiciais não estavam separadas das administrativas, ainda que uma das primeiras medidas consignadas nas Bases da Constituição e especificadas num projecto de Manuel Fernandes Tomás tenha defendido a independência do poder judicial e a sua subsequente separação dos poderes executivo e legislativo (art. $23^{\circ}$ ).

Tomadas as primeiras medidas pelas Cortes de 1821-22, a reforma administrativa e judiciária ficaria suspensa até aos diplomas de José Xavier Mouzinho da Silveira datados de 16 de Maio de 1832 que então defendiam a diferença de administrar e julgar (Relatório). Motivos de natureza política, como as duas restaurações do absolutismo, acabariam por justificá-lo.

2. Algumas seriam, contudo, as medidas judiciárias introduzidas pelo vintismo de que podemos salientar o texto da Carta de Lei de 12 de Novembro de 1822, devida a José da Silva Carvalho ${ }^{6}$ e os próprios textos constitucionais, o de 1822 (arts. $176^{\circ}$ $211^{\circ}$ ) e o de 1826 (arts. $118^{\circ}-131^{\circ}$ e $\left.145^{\circ} \S \S 7-11\right)$.

O primeiro dividiria o território em cinco distritos de Relações, com sede em Lisboa, Porto, Mirandela, Viseu e Beja, ficando as Ilhas adjacentes pertencendo ao distrito da relação de Lisboa (art. $1^{\circ}$ ). Em cada uma delas haveria um presidente, um

${ }^{6}$ In Documentos para a Historia das Cortes Geraes da Nação Portugueza, I, pp.467-478. 
procurador da Soberania Nacional e da Coroa, um procurador da Fazenda, um promotor das Justiças, um solicitador e demais pessoal administrativo, além de um número fixo de desembargadores ${ }^{7}$.

Na sessão n. $^{\circ}$ 282, de 25 de Janeiro de 1822 era prevista a criação tribunais de segunda instância respectivamente para as províncias de Alem-Tejo e Algarve, Estremadura; duas para a Beira; uma para o Minho e Porto; uma em Trás-os-Montes; uma nas Ilhas adjacentes e uma, por fim, uma para cada província do Brasil, do reino da Guiné e dos estados da Índia. A composição e sede destes tribunais seriam determinadas por lei especial não podendo o número dos seus ministros ser inferior a sete, além do presidente e procurador da Coroa.

Todavia, tal como referimos anteriormente, o regresso ao Absolutismo, em Junho de 1823, impediria que estas medidas viessem a ser aplicadas.

3. Já na vigência da Carta Constitucional é discutida a possibilidade de serem criadas seis Relações ${ }^{8}$, sendo entregue o projecto de divisão judicial na sessão de 18 de Janeiro de 1827 a uma comissão legislativa, em cumprimento do disposto nos arts. $118^{\circ}$ e $125^{\circ}$ da Carta. A discussão seria longa e do projecto inicial de criação de seis tribunais de segunda instância são propostos apenas dois9 .

Muito embora o final da década de vinte reitere a necessidade imperiosa de ser redesenhado o mapa judiciário, o período político delimitado entre 1826-1832 não permitirá a efectivação de quaisquer avanços ${ }^{10}$.

Ante este quadro, o reino assiste ainda à saída do Reino de um número considerável de magistrados e funcionários judiciais que rumam ao exílio. Enquanto algumas instituições aguardam pelo momento da sua criação física, como é o caso do Supremo Tribunal de Justiça, que já se encontrava consagrado no texto de $1822\left(\right.$ art. $191^{\circ}$ ) e que a Carta manterá (arts. $130^{\circ}-131^{\circ}$ ); outras esperam a sua extinção efectiva como sucedeu com o Tribunal do Desembargo do Paço, o qual, ainda que a sua extinção tivesse sido determinada pelo texto de 1822, só viria a efectivar-se com o Decreto de

\footnotetext{
${ }^{7}$ Vide Decreto de 22 de Novembro de 1822, in Collecção de Legislação das Cortes de 1821 a 1823, Imprensa Nacional, Lisboa, 1843, pp. 180 e ss.

${ }^{8}$ Vd. discussão na sessão da Câmara dos Deputados de 27 de Março de 1827.

${ }^{9}$ In sessão de 19 de Janeiro de 1828; vd. os testemunhos dos deputados Serpa Machado e Galvão Palma sobre o número total de relações a instituir.

${ }^{10}$ Importa referir que ainda em 1828 José Joaquim Sant'Anna procede à redacção de um projecto de Código de Processo Civil e Criminal, que seria concluído em 1847 e cujo Livro I dispõe acerca da organização judiciária, a qual assentava em distritos judiciais, que correspondiam, cada um, à sede de um tribunal de segunda instância. Mais tarde, nos anos de 1831-32, Silvestre Pinheiro Ferreira apresentará uma proposta de organização judiciária fundada no desenho administrativo, onde se previa a criação de seis instâncias, casas de Relação, juizos de corregedoria, ouvidorias, conservadorias, auditorias e juizos de paz, in Projectos de Ordenações para o Reino de Portugal, tomo II, Paris, Officina Typografica de Casimir, 1831 e Manual do Cidadão em um Governo Representativo, ou Princípios de Direito Constitucional, Administrativo e das Gentes, tomo III, Direito Constitucional, Paris, Grey et Gravier, 1834.
} 
3 de Agosto de 1833. Paralelamente são também mantidos alguns laivos do quadro judiciário anterior a 1820, mormente no que diz respeito aos tribunais especiais e a alguns cargos judiciários, como sucede com os corregedores, os almotacés, os juízes pedâneos e os juízes ordinários.

4. Delimitados, ainda que sumariamente, os contornos do mapa judiciário, 1830 assiste ex vi do disposto no Decreto n. ${ }^{\circ}$ 8, de 27 de Março, à criação de uma Junta de Justiça na cidade de Angra, a qual deverá funcionar enquanto não for possível a instalação da Relação dos Açores.

Desde já parece ser possível avançar com uma característica deste tribunal de segunda instância, a da sua temporaneidade. Com esta solução tentava-se obter a devida aplicação da justiça que, de outro modo, ficaria suspensa dada a ocorrência de vicissitudes políticas que impediam o trâmite processual nos moldes normais.

Convém ainda não esquecer que a criação de um tribunal em Angra não excluiria o respectivo arquipélago seja da área de jurisdição da Casa da Suplicação seja, mais tarde, da Relação de Lisboa. Tampouco se define este território como ultramarino ${ }^{11}$.

\section{A Junta de Justiça}

\section{a. Do projecto efémero da Relação de Angra à criação da Junta de Justiça}

Em 15 de Janeiro de 1829, a Junta Provisória instalada em Angra estando encarregada de manter a legitima Auctoridade de Sua Magestade a Rainha a Senhora Dona Maria Segunda, tomando em consideração os graves prejuizos que soffrem os habitantes destas ilhas na demora da última decisão de suas causas por se achar interrompida a commonicação com os tribunaes do Reino, pelo motivo de se haver ahi manifestado huma rebelião contra os Legitimos direitos da mesma Augusta Senhora, (...) sendo certo que na prompta decizão dos litígios e execução das leys consiste a maior garantia dos direitos sociaes, entende dever proceder-se à criação de uma Relação que tome conhecimento provisoriamente dos agravos, appelaçoens, tanto civis como crimes na forma das leys ${ }^{12}$. O Decreto n. ${ }^{\circ} 19$, de 24 de Janeiro de 1829 determinaria, por sua vez, que todos os negócios que exigissem recurso à Mesa do Desembargo do Paço, e que até então haviam sido decididos pela Junta Criminal criada pelo Alvará de 10 de Setembro de 1811, passariam a ser da competência da Relação, cabendo a sua decisão ao chanceler, na qualidade de presidente e aos dois desembargadores mais antigos. Deste modo e enquanto estivesse em funcionamento a mesma Relação encontrava-se suspensa a Junta Criminal ${ }^{13}$.

\footnotetext{
${ }^{11}$ Recorde-se que, com a independência do Brasil, o número de Relações resumia-se a quatro (Lisboa, Porto, Luanda e Goa), uma vez que haviam sido extintas as da Baía, do Rio de Janeiro, Maranhão e Pernambuco.

${ }^{12}$ In Decreto de 15 de Janeiro de 1829, cfr. doc. de fls. 2-2v.

${ }^{13}$ In Decreto n. ${ }^{\circ}$ 19, de 24 de Janeiro de 1829, a fls. 6v.
} 
Reconhecida a necessidade da criação desta Relação, era nomeado a 15 de Janeiro de $1829^{14}$ para seu chanceler o Dr. João José da Cunha Ferraz ${ }^{15}$. Para ministros da mesma Relação eram designados os desembargadores Luís Ribeiro de Sousa Saraiva ${ }^{16}$ e António da Cunha Vasconcelos ${ }^{17}$, o Doutor Manuel José de Meirelles Guerra, corregedor da comarca de Angra ${ }^{18}$ e o Doutor José Jacinto Valente Farinho, juiz de fora

${ }^{14} \mathrm{O}$ chanceler da Relação seria igualmente o chanceler dos negócios de graça, nos termos do Decreto n. ${ }^{\circ}$ 16, de 17 de Janeiro de 1829. A este cargo seriam aplicadas as regras do Regimento constante no Livro I, titulo 2, das OF. o que revogava a aplicação do Decreto de 7 de Janeiro de 1829. Vide doc. de fls. 2v.-3.

${ }^{15}$ João José da Cunha FERRAZ (Angra do Heroísmo, 24 de Março de 1761-Sé (Angra do Heroísmo), 3 de Fevereiro de 1844), político, eclesiástico, provisor, tesoureiro-mor e presidente do Cabido da Sé de Angra. Destaca-se ainda como defensor do movimento liberal, tendo presidido à Junta Provisória instituída em Angra e ao Governo interino formado na Terceira antes da instalação da Regência naquela ilha. É um dos vultos mais proeminentes do movimento liberal, e dos que mais concorreram para a proclamação de 22 de Junho de 1828.

Desempenhou ainda as funções de chanceler da Relação da Província dos Açores até Setembro de 1829, data da suspensão da Relação, passando em seguida a ser o presidente da Junta de Justiça, ex vi do Decreto de 27 de Março de 1830.

Ser-lhe-ia concedida a jubilação na qualidade de desembargador do paço por Decreto de 30 de Maio de 1832, sendo aposentado na dignidade de Arcediago na Sé Catedral de Angra do Heroísmo, visto ter quarenta anos de murçado na mesma Santa Sé, com todas as proeminências e honras próprias da sua Cadeira tanto no Coro, Cabido, e fora da Sé usando hábitos Canonicais próprios da sua dignidade, voto e stálo em todas as ocasiões, em que se apresentar na mesma Sé e Cabido, como até agora sempre usou, podendo residir, ou deixar de residir na mesma Sé, e na ilha Terceira, ou em qualquer parte fora do Bispado dos Açores. Vide doc. de fls. 41v.

${ }^{16}$ Luís Ribeiro Barbas de Sousa SARAIVA, 1786 ou 1788 (Manteigas)-1854 (Lisboa). Filho de Manuel Ribeiro Castelo Branco e de D. Maria Gertrudes Borges Cabral de Sousa da vila de Manteigas, comarca da Guarda. Neto paterno de Luís Ribeiro Barbas e de D. Rosa da Conceição da mesma vila de Manteigas e neto materno de Manuel Saraiva da vila de Santa Marinha e de D. Ângela Maria Cabral de Sousa, de Fazem, termo de Ceia, da mesma comarca da Guarda (cfr. Iantt, Leitura de Bacharéis, 1811, maço 17, n. ${ }^{\circ}$ 48). Em 1803 inscreve-se no curso de Matemática (1803) a que se segue a matrícula em Teologia (1804), curso que frequenta durante dois anos. A matrícula em Cânones ocorreria apenas em 1806, vindo a obter o grau de bacharel em 1808. Como juiz de fora exerce funções nas comarcas de Seia e do Funchal (1819-1821), seguindo-se as de corregedor de Viseu (1821), vogal efectivo do Conselho de Justiça de Angra, membro da Junta de Justiça de Angra, desembargador das Relações de Lamego e de Lisboa, conselheiro do STJ (1834-1840) e juiz relator do Supremo Conselho de Justiça Militar. Desempenhou ainda as funções de subprefeito da comarca de Ponta Delgada (1832-33), assim como integrou algumas legislaturas, na qualidade de deputado, tendo pertencido durante vários anos às Comissões de Justiça e Legislação e de Infracções.

${ }^{17}$ António da CUNHA E VASCONCELOS (1784, São Martinho de Soalhães, comarca do Porto), filho de Máximo António da Cunha e de D. Matilde Rosa de Vasconcelos. Neto paterno de Teodósio Cerqueira e de D. Lourença de Jesus e Almeida. Neto materno de Francisco Pinto Villa Lobos e de D. Ana Joaquina de Gouveia, natural do concelho de Soalhães da comarca do Porto, segundo informação constante do seu processo de leitura de bacharéis, 1812, maço 40, letra A, n. ${ }^{\circ} 25$ (Iantt). Bacharel em leis, desembargador.

${ }^{18}$ Manuel José de Meirelles GUERRA (1780, Moncorvo), filho de José António de Meirelles Guerra e de Ana Joaquina de Sousa, de Torre de Moncorvo. Neto paterno de Manuel António Domingues e Joana Maria. Todos da mesma vila e comarca de Moncorvo (in Iantt, Leitura de Bacharéis: 1815, maço 
de Angra ${ }^{19}$. Como adjuntos jurariam o doutor João Silveira da Luz, juiz de fora da vila da Praia ${ }^{20}$, o provedor Pedro da Fonseca Veloso ${ }^{21}$, Francisco de Assis Gomes de Miranda, juiz de fora $^{22}$ e José Pereira Leite Negrão $0^{23}$; os quais tomariam posse a 18 de Julho de $1829^{24}$.

58, n. ${ }^{\circ}$ 19). Bacharel em Leis (1815) e corregedor da comarca de Angra. Neste mesmo manuscrito da Relação de Angra é copiada uma portaria que o exclui do exercício do cargo de corregedor, sendo substituído pelo desembargador Luis Ribeiro Saraiva (a fls. 33-33v). Trata-se do Decreto de 4 de Dezembro de 1830, segundo o qual em atenção ao merecimento e mais partes que concorrem na pessoa do bacharel Luis Ribeiro de Sousa Saraiva, Há por bem a Regência em nome da Rainha provelo no lugar de corregedor de Angra com a graduação de desembargador da Casa e Relação do Porto ficando ao mesmo tempo exonerado do lugar que ocupa (...) sendo necessário que o lugar de corregedor d'Angra ocupado por um magistrado vigilante na guarda e manutenção da paz e tranquilidade pública, pronto no lançamento e cobrança de impostos, zeloso e diligente nas execuções dos acórdãos da Fazenda Pública, não convindo portanto ao Real Serviço que o bacharel Manuel José Meirelles Guerra continue a servir aquele lugar, para o qual foi provisoriamente nomeado, pela junta que governou esta província, e ocorrendo ter o mesmo bacharel pedido a sua demissão pela causa de moléstia que não justificou, quando lhe foi ordenado, Há por bem a Regência em nome da Rainha exonerá-lo do sobredito emprego e todos os outros que the andam anexos (...) Palácio do Governo em Angra, 4 de 12.1830= Marquês de Palmela = Conde de Vila Flor = José António Guerreiro = Luis da Silva Mouzinho de Albuquerque (ibidem).

${ }^{19}$ José Jacinto Valente FARINHO nasceu em Beja a 18 de Agosto de 1792 e morreu na mesma cidade a 24 de Julho de 1855. Bacharel em Direito pela Universidade de Coimbra, juiz na ilha Terceira em 1831, onde esteve implicado numa conspiração saldanhista que visava, ao que se disse, a deposição e assassínio do Marquês de Palmela. Indiciado na devassa feita pelo juiz de fora de Angra, foi expulso para Inglaterra juntamente com vários elementos militares. Anos depois foi ministro dos Negócios Eclesiásticos e de Justiça, num ministério presidido por Saldanha entre 6 de Outubro de 1846 e 28 de Abril de 1847. Foi também presidente do tribunal comercial de $2^{\mathrm{a}}$ instância. Em 1841 foi vice-presidente da Câmara dos Deputados. Foi eleito deputado para três legislaturas: 1838-1840, 1840-1842 e 1851-1852 tendo sido sempre eleito pelo círculo plurinominal de Beja.

${ }^{20}$ João Silveira da LUZ, filho de José Silveira Ferreira, natural da Ilha de S. Jorge. No ano lectivo de 1819-1820, o seu nome constava do rol de alunos inscritos no $2^{\circ}$ ano jurídico (vd. Relação e Índice alphabetico dos estudantes ...), p.13.

${ }^{21}$ Pedro da Fonseca Serrão VELLLOSO (Abrantes,1781-Lisboa,1843), filho de Joaquim António Duarte da Silva Veloso e de Helena Justina da Fonseca e Sousa, neto paterno de António Duarte de Serrão Velloso e de D. Catarina Teresa Velloso e materno de António Tomás da Fonseca e de D. Maria Clara de Figueiredo. Todos da vila de Abrantes (Iantt, Leitura de Bacharéis, 1804, maço 9, n. ${ }^{\circ}$ 12). Bacharel em Leis (1803), membro do Conselho de Justiça e da Junta de Justiça criado em Angra, deputado para a legislatura de 1842-1845 por Trás-os-Montes, tendo jurado a 9 de Janeiro de 1843.

${ }^{22}$ Francisco de Assis Gomes de MIRANDA (1800, Torres Vedras), filho de José Gomes de Miranda e de Maria Paula de Azevedo, ambos de Torres Vedras. Neto paterno de António Gomes e de Maria Gracia, ambos do lugar da Paúlha ou Paúl, termo de Torres Vedras. Neto materno de Domingos Alves, natural de Casalinhos d'Alfaiata, termo de Torres Vedras e de Maria Josefa, natural de Alcobaça (in Iantt, Leitura de bacharéis, 1824, maço 25, n. ${ }^{\circ}$ 24). Bacharel em Cânones (1823) e desembargador da Relação de Lisboa (cfr. Iantt, MNEJ, maço 359/7).

${ }^{23}$ José Pereira Leite Pita d' Ortigueira NEGRÃO. Filho de Manuel Joaquim Lopes Pereira Negrão, natural de Vila de Azuras, comarca do Porto e de D. Maria Bernarda Freire Leite Pitta da Ortigueira, natural de Barcelos. Neto paterno de José João Lopes Negrão e de D. Maria Josefa Guiomar do Nascimento (?), naturais da Vila de Azuras. Neto materno de José António Ferreira, natural de Barcelos e de D. Isabel Clara Leite Pitta da Ortigueira, natural da vila de Caminha, comarca de Valença do Minho (in 
Assim constituída, a Relação de Angra contava com o número de magistrados necessários que venceriam ordenados idênticos aos desembargadores da Relação e Casa do Porto ${ }^{25}$.

Na qualidade de empregados no expediente da Relação, prestariam juramento os escrivães Vicente Pereira de Mattos, Joaquim Pinheiro da Silva, José Hilário Lopes Ameno (distribuidor), António Silveira Machado (tesoureiro), Manuel Joaquim de Faria (porteiro) ${ }^{26}$, José Maria Monteiro (meirinho) e Joaquim José Brasil (porteiro da chancelaria $)^{27}$.

Em virtude da inexistência de um Regimento que se aplicasse a este tribunal ${ }^{28}$, o governo da Regência incumbiria o chanceler e demais desembargadores e adjuntos da execução de um regulamento e organização, assim como lhes atribuía a tarefa da criação e designação do juiz dos feitos da fazenda e coroa, do corregedor do crime, promotor das justiças e decisão de casos novos. Estas propostas, uma vez elaboradas, deveriam ser encaminhadas à Regente ${ }^{29}$. Sem que uma causa em concreto tenha sido apresentada, o trabalho fica sem efeito e a Relação será suspensa, acto que terá por consequência a instituição da Junta Criminal, por acto da mesma Junta Provisória, tomado em 3 de Setembro de 1829 em conformidade com o disposto no Alvará de 15 de Novembro de 1810. Uma vez recriada, a Junta Criminal a sua presidência é conferida ao conde de Vila Flor, dela fazendo ainda parte os três ministros territoriais em exercício de funções na Ilha Terceira e os Doutores Luís Ribeiro de Sousa Saraiva, António da Cunha Vasconcelos e Pedro da Fonseca Serrão Veloso ${ }^{30}$.

Iantt, Leitura de bacharéis: 1824, maço 79, n. ${ }^{\circ}$ 5), bacharel em Leis (1822), cfr. Relação e Índice alphabetico dos estudantes matriculados na Universidade de Coimbra no Anno lectivo de 1821-1822, suas naturalidades, filiações e moradas, p. 26; tendo procedido à leitura no Desembargo do Paço em 1823.

A tomada de posse teria lugar a 18 de Julho de 1829, conforme doc. de fls. 8v. Mais tarde a Portaria de 18 de Julho de 1829 daria posse ao corregedor da comarca de Angra, Manuel José de Meirelles Guerra, ao juiz de fora da Vila da Praia, João Silveira da Luz, aos bacharéis Pedro da Fonseca Velloso, Francisco de Assis Gomes de Miranda, Manuel Joaquim Nogueira, António Barreto Ferreira Gravito e José Pereira Leite Pita Negrão, habilitando-os ao exercício de funções junto da mesma Relação, conforme doc. de fls. $10 \mathrm{v}-11$.

${ }^{24}$ Vide doc. de fls. $11 \mathrm{v}-12$.

${ }^{25}$ Para esta Relação deveriam ser nomeadas as pessoas que se ocupassem já cargos judiciais, de modo a evitar gastos extraordinários, conforme decorre do disposto na Portaria de 16 de Janeiro de 1829, a fls. 3-3v.

${ }^{26}$ Terá estado preso em Angra nos dias 3 e 4 de Agosto de 1823, durante o governo de D. Miguel (in Anais da Ilha Terceira, Doc. L, citado no tomo IV).

${ }^{27}$ Cfr. doc. de fls. $5 \mathrm{v}-6$.

${ }^{28}$ Vide Portaria de 28 de Julho e Ofício de 11 de Agosto, ambos de 1829 e do Conde de Vila Flor, a fls. $12 \mathrm{v}-13 \mathrm{v}$.

${ }^{29}$ Vide docs. de fls. $12 \mathrm{v}-13 \mathrm{v}$.

${ }^{30}$ Vide docs. de fls. 14-14v que procedem à cópia do Oficio e Portaria pela qual se suspende a Relação e se instalou a Junta de Justiça Criminal em armonia com a forma de governo ora existente nesta província.(...) Hei por bem haver por instalada a Junta Criminal na conformidade do mesmo alvará (de 15 de Novembro de 1810) comporão a Junta criminal por mim presidida [Conde de Vila Flor é o autor deste 
Se a primeira tentativa de criar um tribunal de segunda instância, em 1829, não tinha vingado, a re-instituição da Junta Criminal também ficaria sem efeito tendo sido substituída pela Junta de Justiça instituída em 27 de Março de $1830^{31}$.

Assim a Junta de Justiça, ou Junta Suprema de Justiça, como a designaria o diploma de 1832, distinguir-se-ia, desde logo, da Junta de Justiça Criminal e do Supremo Conselho de Justiça instituídos ambos ex vi do disposto do §10 do Alvará de 15 de Novembro de $1810^{32}$. Esta entidade judicial não pretende ser um somatório das

documento) e três ministros territoriais desta ilha, além deles os seguintes magistrados, por serem os mais graduados que nele existem como determina o alvará supra citado. O Doutor Luis Ribeiro de Sousa Saraiva, o Doutor António da Cunha Meirelles, o Doutor Pedro da Fonseca Serrão Velloso. Os três últimos magistrados vencerão além do subsídio que Sua Magestade lhes conceder a gratificação que lhes assina o citado alvará. Palácio do Governo em Angra 2 de Setembro de 1829. Conde de Vila Flor.

${ }^{31}$ No dia 6 de Março de 1832, foi a Junta de Justiça visitar a Sua Majestade Imperial, e o seu presidente lhe dirigiu a seguinte fala: A Junta de Justiça, criada em 27 de Março de 1830, por decreto da Regência do Reino em nome da Rainha, para servir de tribunal de apelações em segunda e última instância nesta provincia dos Açores, vem hoje, perante Vossa Majestade Imperial, oferecer os seus respeitos e homenagem, e dar a Vossa Majestade Imperial os devidos parabéns pela sua feliz viagem e actual residência neta memorável ilha, assim como notificar de novo os seus protestos e juramentos a bem da causa da senhora D. Maria II, nossa Augusta Rainha, bem Digna Filha de Vossa Majestade Imperial. A Junta, Senhor, aproveita com sumo prazer, a ocasião tão oportuna de manifestar da sua parte, e se lhe é lícito ainda fazê-lo, em nome da magistratura portuguesa, fiel nos sentimentos de gratidão ao Ínclito Autor da Carta Constitucional da Monarquia, dádiva preciosa que laureia de glória o soberano que a liberaliza e vai cobrir de glória os súbditos que a recebem, reconhecimento este que se tornará mais profundo e obrigatório com a certeza que Vossa Majestade, digno restaurador dos foros portugueses, vai pessoalmente ordenar-lhe a pátria, marcar-lhe o devido andamento e vigiar a sua pontual execução, sem o que, obra tão iminente e benéfica não passará de uma filosofia e bem reconhecida teoria política. Os incómodos, os sofrimentos, os perigos, sustos e receios que até agora acompanharam sempre os fiéis súbditos da nossa Augusta Rainha, vão desaparecer ao brilho da mais consoladora esperança, a de voltar à desejada pátria, e sua recordação se conservará unicamente para esmalte de tão resplandecente perspectiva. Portugal; o enlutado Portugal, antolha com júbilo o porvir da sua próxima felicidade, e não obstante as cadeias que a oprimem, levanta aos céus os enfraquecidos braços, implorando os socorros que espera de um dos pontos mais notáveis do Oceano Atlântico: ele não tarda, e Vossa Majestade Imperial, abraçado ao santo amor da pátria, em breve aportará às praias lusitanas, que o viram nascer, para restaurar e libertar do cativeiro a Nação Portuguesa, esmagada por um partido atroz e sanguinário e lançar ali os fundamentos de um novo edifício social, de que é o insigne Arquitecto. A Junta, havendo feito a declaração dos seus verdadeiros sentimentos, roga a Vossa Majestade Imperial se digne recebêlos e aliviá-los com a sua costumada benevolência, da qual se fazem merecedores pela sinceridade com que são ditados e exprimidos: permitindo ao mesmo tempo Vossa Majestade Imperial a recompensa de os conservar em lembrança para honra e conservação da mesma Junta, a qual se persuade ter, com a presente respeitosa exposição, satisfeito ao dever do reconhecimento, que tributa a Vossa Majestade Imperial e ao da obediência devida à senhora D. Maria II, nossa Augusta Rainha.

A resposta do imperador foi nos seguintes termos: Recebo com especial agrado as expressões e os sentimentos da Junta de Justiça. (in Anais da Ilha Terceira). Vide doc. de fls. 14v.

${ }^{32}$ Determinava o Alvará de lei de 15 de Novembro de 1810 a criação de uma Junta Criminal a fim de que com a conveniente brevidade, e com o devido exame, e legalidade, se processassem, e punissem os Réos pelos crimes por eles perpetrados (pr), a qual seria estabelecida na cidade de Angra, sendo composta por um presidente e seis vogais efectivos e dos extraordinários (I). O Governador e capitão general 
anteriores, nem tampouco espelhar a continuidade de uma delas. Será antes um novo órgão do poder judiciário com competências próprias, as quais, como veremos, extrapolariam as das entidades substituídas.

Saliente-se, ainda, que nos termos do Decreto n. ${ }^{\circ} 18$ de 24 de Janeiro de 1829 se procedera à suspensão do exercício da Junta Criminal, a qual sub-rogava as suas funções na Relação de Angra $^{33}$. Por sua vez, o Supremo Conselho de Justiça seria substituído temporariamente (ex vi do Decreto de 14 de Novembro de 1828) pelo Conselho Militar (também designado Conselho de Justiça) nos termos do Decreto de 14 de Novembro de $1828^{34}$ e da Portaria do Governador e Capitão General dos Açores, de 15 de Julho de $1829^{35}$.

seria o seu Presidente, sendo substituído pelo Bispo. Na falta de ambos, este lugar seria ocupado pelo oficial militar sobre quem tivesse recaído o Governo (II). Os vogais efectivos correspondiam aos ministros letrados residentes da Ilha Terceira. Não os havendo em número suficiente, seriam convocados os bacharéis que na mesma ilha se encontrassem empregados no Real Serviço. Não se verificando esta condição, estas funções eram desempenhadas por aqueles que tivessem antes servido lugares de letras, preferindo uns aos outros pelas suas graduações e antiguidade. Na falta destes seriam convocados os ministros letrados das outras ilhas atendendo á proximidade geográfica (III).

A citada Junta sentenciaria em uma só e última instância os réus de todos e quaisquer crimes que não coubessem na alçada dos magistrados territoriais, à excepção dos réus eclesiásticos e dos militares que gozassem do privilégio de foro. As sentenças proferidas em Conselho de Guerra que na conformidade do Aviso de 16 de Abril de 1806 e do Alvará com força de lei de 1 de Abril de 1808 deveriam ser remetidas ao Conselho Supremo militar, passariam a ser enviadas à Junta de Justiça das Ilhas dos Açores, nomeando, neste caso, o Presidente três vogais militares da maior graduação que se encontrassem na ilha Terceira e não tivessem impedimento legítimo para votar (X). Cabia à mesma Junta conhecer da pronúncia dos réus de crimes capitais, bem como os autos originais e devassas (XI); assim como dos agravos interpostos de processos-crime (XII). Deveria a mesma Junta, com o parecer do presidente, suprir qualquer nulidade do processo guardada a forma prescrita nas OF 1,5,12 e pelo assento da Casa da Suplicação de 20 de Março de 1606 (XIV). Em tempo de paz, sendo lavrada sentença de morte natural ou civil, cortamento de membro, ou aplicação de pena infamante, deveria a mesma Junta Criminal propor tais decisões à consideração régia, por meio da Secretaria de Estado dos Negócios da Marinha e dos Domínios Ultramarinos (XV). Nos demais crimes poderia o presidente comutar a pena, desde que obtivesse a pluralidade dos votos dos vogais, nos termos do n. ${ }^{\circ}$ XVIII. Em tempo de guerra, a Junta faria executar as suas sentenças, independentemente da qualidade da pessoa, nos casos de espionagem, deserção para o inimigo, sublevação, traição e motim (XVI). A execução das sentenças poderia ainda ser suspensa, devendo para tanto ter o parecer do presidente e a pluralidade de votos quando se entendesse ser caso de aplicação de clemência régia (XVII).

${ }^{33}$ Vide doc. de fls. 6v.

${ }^{34}$ In José Ricardo da Costa Silva Antunes, Compilação da Legislação Penal Militar desde 1446 até 30 de Junho de 1895, s.n., Lisboa, 1895, p. 141. Deste Conselho Militar faziam parte um presidente, um juiz relator, cinco vogais ordinários e dois extraordinários para os casos de empate. O já citado diploma de 1829 em conformidade com o disposto no Alvará de 15 de Novembro de 1810 e do Decreto de 13 de Agosto de 1790 reconhecia-lhe jurisdição, arbitrio e faculdade para confirmar, revogar, alterar e modificar as sentenças dos conselhos, quer condemnem, quer absolvam nos casos em que o direito o permitte, dando-se á execução as sentenças assim confirmadas pelo dito supremo conselho na forma regulada pelo decreto de 20 de agosto de 1777, e como se acha declarado no decreto de 13 de Novembro de 1790 (...) para os crimes de espia, deserção para os inimigos, sublevação, traição e motim, em cujos casos, praticando o dito supremo conselho militar exactamente o que as leis ordenam, remetterá as fi- 


\section{b. Localização e sede}

Por determinação do Decreto n. ${ }^{\circ}$ 8, de 27 de Março de 1830, não sendo praticável a instauração de uma Relação na província dos Açores, e exigindo o bem dos leaes habitantes (...) haverá na cidade de Angra uma Junta de Justiça (...) que se reunirá todas as Segundas, Quartas e Sextas feiras de cada semana, ou no dia seguinte, sendo alguns destes feriados $\left(n .^{o s} 1^{\circ}\right.$ e $\left.8^{\circ}\right)$. Seriam guardados na qualidade de dias festivos apenas os dias santos, não havendo lugar a período de férias, como é costume e prática ${ }^{36}$.

Cerca de dois anos mais tarde, em 5 de Abril de 1832, um Aviso do Presidente da Junta reiteraria a mesma regra quanto à periodicidade das suas reuniões, o que excluía, tal como o decreto de 1830 , a suspensão no período de férias como era costume e prática.

Em cumprimento do Aviso da Secretaria de Estado, de 31 de Março de 1830, a sala da Câmara era destinada para as sessões da Junta de Justiça, tendo sido instalada na forma dos Decretos que forão presentes e lidos neste acto ${ }^{37}$.

\section{c. Natureza jurídica deste tribunal}

Em virtude dos conflitos internos decorrentes da sucessão ao trono e da defesa dos direitos de D. Maria, este tribunal revestiria contornos unicamente pontuais. Por este motivo e dada a natureza das suas competências, não o consideramos nem um tribunal

naes sentenças, antes de publicadas, e com todo o segredo de justiça, á presença da junta provisória, com aquellas recommendações que as circunstancias declarem, a fim de que a mesma junta, em nome de El-rei haja de resolver sobre a sua final execução. Vd. ainda a Portaria do Governador e Capitão-General dos Açores de 15 de Julho de 1829.

Em 1830, a Regência então instalada nos Açores determinaria a nova composição deste Conselho de Justiça. Dele fariam, então, parte, o brigadeiro Conde de Alva, o coronel António Pedro de Brito e o coronel José Rodrigo de Almeida, e os vogais letrados, Luís Ribeiro de Sousa Saraiva, que desempenhava as funções de relator, o corregedor de Angra, Manuel José de Meirelles Guerra e o bacharel Pedro da Fonseca Serrão Velloso. O mesmo decreto da Regência reconhecia competência ao Conselho de Justiça para conhecer dos casos que pertenciam ao Supremo Conselho Militar ou Conselho de Justiça, como aqueles que pelo Aviso de 16 de Abril de 1806 e pelo $\$ 10$ do Alvará de 15 de Novembro de 1810 deviam ser decididos pelo capitão general com o corregedor da comarca.

${ }^{35}$ Segundo a letra desta portaria, o Conselho de Justiça seria composto por um presidente, três vogais militares e três vogais letrados, sendo relator o mais graduado e em igual graduação, o mais antigo, entre os vogais letrados. O presidente seria o governador e capitão general da província, os três vogais militares seriam os oficiais de superior patente e antiguidade existentes na ilha Terceira e os três vogais letrados corresponderiam aos desembargadores da Relação dos Açores e o corregedor da cidade de Angra. Sobre a composição deste mesmo Conselho, vd. o Decreto da Regência dos Açores, de 27 de Março de 1830. ${ }^{36} \mathrm{Vd}$. Aviso de 5 de Abril de 1832, a fls. 58. Recorde-se ainda que o calendário judicial consagrava para além dos períodos de férias, os dias de grande e simples gala. No entanto, estas datas não implicavam a autorização tácita de ausência da comarca por parte do magistrado, ou mesmo dos funcionários judiciais, que apenas o poderiam fazer desde que lhes fosse concedida autorização prévia. Vide doc. de fls. 15. ${ }^{37}$ Cfr. auto de instalação datado de 2 de Abril de 1832, a fls. 15. 
político como o que havia sido proposto em 1822 para conhecer dos crimes dos deputados e dos crimes contra a segurança do Estado, nem especial ou de excepção de que eram exemplo o Supremo Tribunal de Imprensa e a Câmara dos Pares. Ao invés, tratava-se de um juízo comum criado $a d h^{38} c^{38}$. Note-se que a classificação que agora adoptamos não pretende aplicar qualquer consideração doutrinária coeva que ora excluía ora aceitava a legitimidade dos tribunais especiais invocando, no primeiro caso o seu carácter odioso e a violação ao princípio da igualdade perante a lei (Bentham, Silvestre pinheiro Ferreira, Silva Ferrão e Rámon Salas). Além do mais, a doutrina oitocentista é totalmente omissa no que diz respeito à apreciação deste tribunal.

Excluímos, igualmente, a possibilidade de se tratar de um tribunal revolucionário, isto é, de um tipo particular de tribunal especial de natureza política em cujas decisões não influem os princípios da justiça, da razão, as regras de direito, as de hermenêutica jurídica, as da imparcialidade; não hesitando os que os compõem em agradar a quem os nomeou.

Deste modo, e partindo da divisão doutrinária que divide os tribunais em duas classes: os tribunais comuns e os tribunais de excepção ou especiais ${ }^{39}$, sendo aqueles os que conhecem da generalidade das causas cíveis e criminais, independentemente da qualidade das pessoas que nelas intervenham e estes das causas de natureza especial em razão da matéria sobre que versam e da qualidade das pessoas a que as mesmas causas respeitam, entendemos que a Junta de Justiça configura um exemplo de tribunal comum. Ademais e porque os tribunais de excepção constituem uma restrição à jurisdição e competência dos tribunais comuns, não pode cometer-se-lhes conhecimento de objecto que não esteja expresso na lei, ou que dela se não deduza, entendendo sempre restritivamente aquela jurisdição e competência Mas, este não era o caso da Junta de Justiça, como veremos.

\section{d. Competência}

1. Tal como referimos anteriormente, entendemos que a criação da Junta de Justiça de Angra não configura um exemplo de um tribunal especial, ou mesmo de jurisdição privilegiada e a comprová-lo passaremos a enunciar o leque de competências que a legislação em vigor lhe conferiu.

\footnotetext{
${ }^{38}$ Com base na literatura anterior ao séc. XVIII a distinção estabelecida entre os tribunais comuns e especiais estava baseada sobretudo na origem dos poderes jurisdicionais. A ordinária que era inerente por natureza à própria magistratura, enquanto a extraordinária (delegata, mandata) era concedida por um mandato especial. Os magistrados ordinários tinham, portanto, uma jurisdição própria, ao passo que os extraordinários apenas gozavam do "uso da jurisdição"; correspondendo os primeiros ao próprio Rei, aos membros dos tribunais superiores, corregedores e juízes ordinários das terras.

${ }^{39}$ Para Bentham seriam tribunais especiais os tribunais marciais, a jurisdição exercida nos navios mercantes, o tribunal eclesiástico e o poder judiciário nas assembleias representativas (In De l'organisation judiciaire et de la codification, Bruxelles, Louis Hauman et Compagnie, libraires, 1830, cap. V, p. 7).
} 
Se por um lado o Decreto de 27 de Março de 1830 parece contrariar a letra do diploma de 1829, ao explicar a necessidade da criação de uma Junta de Justiça, à qual não era dada a classificação de Relação, ainda que na teoria the fossem conferidas algumas das competências de tribunal de segunda instância, não podemos esquecer que à revelia do disposto consagrado na Carta de Lei de 2 de Novembro de 1822 (art. $2^{\circ}$ ) e no próprio texto constitucional (art. $190^{\circ}$ ) se verifique legitimamente a fundação deste órgão do poder judiciário que sem revogar os modelos legais vigentes ou alterando o mapa judiciário, irá coexistir com o quadro judiciário instituído e a instituir.

Defendemos, então, que a criação deste juízo permitiu a instauração de um foco de justiça autónoma e próxima dos ideais liberais face ao continente do Reino que se encontrava sob o jugo do governo miguelista. Os magistrados que a integrarão não dependerão de nomeação régia, entenda-se do governante em exercício, mas de um acto dos membros da Regência.

Se este tribunal não recebe a classificação de Relação, entendemos que não é apenas por meras razões terminológicas, ou ainda porque não se queira redefinir o mapa judiciário, mas porque o seu conjunto de competências acaba por integrar um leque mais variado de matérias do que aquele que era conferido a um tribunal de segunda instân$\operatorname{cia}^{40}$. Assim, é-lhe atribuído o conhecimento de matérias do foro criminal, cível e da fazenda, sendo-lhe aplicado inclusive o Regimento da Relação do Porto, reconhecendo-lhe, por analogia, a natureza jurídica de tribunal de segunda instância; ao mesmo tempo que, a legislação posterior ao decreto de Março de 1830 lhe permite substituir, em alguns aspectos, a Mesa do Desembargo do Paço. Subsidiariamente era-lhe aplicada a letra do art. $2^{\circ}$ da Carta de Lei de 2 de Novembro de 1822, considerando-o igual em graduação e alçada aos demais tribunais de segunda instância, o que tornava possível a sua inserção na linha do cursos honorum da magistratura togada. Não podemos deixar de notar uma habilidade no ajustamento legislativo à situação política vivida.

Face aos motivos ora invocados, concluímos que este tribunal é competente para conhecer de matérias do foro criminal e civil, tal como ocorria com a Relação de Lisboa, que na qualidade de tribunal de segunda instância conhecia das apelações e agravos dos feitos que subiam por agravo da Relação do Porto e dos agravos ordinários interpostos dos juízes de maior graduação (cfr. Lei de 18 de Agosto de 1769, O.F., 1.5.5, 1.6, pr. e 1.36, $\left.\mathrm{pr}^{41}\right)$.

Em suma e tal como era concedido às demais Relações, a Junta de Justiça podia conhecer e decidir em segunda e última instância todas as todas as apelações e agravos

\footnotetext{
${ }^{40}$ Cfr. Aviso de 5 de Maio de 1831.

${ }^{41}$ Vd. Ordenações Filipinas, fac simile da edição de Candido Mendes de Almeida de 1870, Fundação Calouste Gulbenkian, Lisboa, 1985.

Vide respectivamente o Decreto de 27 de Março de 1830, o Aviso de 31 de Março de 1830; o Aviso e Decreto de 2 de Abril de 1830 e o Decreto de 2 de Abril de 1830. Nos termos do Aviso de 20 de Abril de 1830 era igualmente reconhecida competência para os feitos cujas assinaturas já haviam sido pagas, os quais deveriam ser distribuídos.
} 
que a ela vierem, dos juízes de primeira instância, guardando, em quanto for possível, o Regimento da Relação e Casa do Porto (art. $3^{\circ}$ do Decreto de 27 de Março de 1830) ${ }^{42}$. Em sede de interposição de agravos e apelações ${ }^{43}$ na Junta de Justiça não teriam voto os juízes de quem se agravou ou apelou, ainda fossem membros daquela. No

\footnotetext{
${ }^{42}$ Portaria de João d'Ávilla em que pede se lhe conceda a revista em hua cauza de injuria, e juntamte vai a Informação.
}

Ministro dos Negócios Eclesiásticos e de Justiça

Manda o duque de Bragança, Regente em nome da Rainha, remetter à Junta de Justiça o incluzo requerimento de João d'Avilla em que pede se lhe conceda revista, em hua cauza de injuria que move a João Pacheco, na qual tendo obtido sentença a favor, diz ter sido depois proferida sentença contraria a fim de que a Junta de Justiça informe sobre tal pretenção, interpondo o seo parecer. O q. assim communico a V. Ma para que, fazendo o presente em sessão se cumpra. Deos gde a V. M ${ }^{a}$ Peço em Angra 22 de Março de 1832 - José Xavier Mouzinho da Silveira = Sr. Presidente da Junta de Justiça= Accordão em Junta para que se cumpra. Angra 26 de Março de $1832=$ Braklami $=$ Costa Cabral= Silva Sousa= Serrão Velloso $=$ Negrão $=$ Coelho e Souza $=$ Senhor $=$ Em cumprimento do Aviso de 22 do corrente, documento em que Vossa Magestade Imperial he servido Mandar que esta Junta Informe com o seo parecer o Requerimento de João d'Avilla em que pede se lhe conceda revista em hua cauza de injuria que move a João Pacheco, tem a mesma a levar ao conhecimento de V. Magestade Imperial o seguinte: que fazendo subir os Autos de que tratta aquelle requerimento, observou que o Suppte teve no juízo do G.al desta Cid.e hua única sentença a seo favor, a qual sendo appelada pelo Supplicado p. ${ }^{a}$ esta Junta foi reformada por falta de hua prova pela e concludente que a Lei exige para a imposição das penas de que faz menção a sentença recorrida o que assim foi declarado por Accordão de 3 de Outubro do anno passado proferido este julgado contra o Supplicante pelos ditos fundamentos embargou este na Chancellartia aquelle Accordão, recurso que lhe foi da mesma maneira desprezado por Accordão de 14 de Novembro do m.mo anno, e advertido seo Advogado $p^{a}$ não abusar do Nobre cargo que exercia, e conservar em juizo a dignidade própria delle, cujo desprezo foi motivado por serem aquelles embargos compostos de matéria velha, e discutida, e já ponderada pelos juizes nos julgados. Esgutados os recursos Ordeniarios que o Supplicante tinha, veio este em Segundos embargos na Chancelaria a hua sentença , e sentença que havia transitado em julgado pela mesma Chancelaria, o que se referiu em 11 de Janeiro prossimo passado, os quaes lhe foram judicialmente desprezados, por Accordão de 29 de Fevereiro passado com jurídico fundamento se serem contrários à Lei semelhantes embargos e como taes por ella condemnados. Por três differentes vezes se proferiu nesta Instancia sentença contra o Supplicante as quaes a Junta julga legaes e proferidas segundo aprova dos Autos, como lhe prescrevia o seo dever. Convencida esta Junta que as mais decisões forão conformes com a Lei e adequadas às provas que encontrou, só terá que dizer a Vossa Magestade Imperial que huma tal pretensão além de não ter motivo justificado parece offensiva à Lei do reino, a qual marcando a Alçada desta Junta pelas attribuições que lhe forão dadas hia muito inferir à sua quantia a de cem mil réis, vaslor attribuido aquella cauzapara o grão de Appelação, e por consequência comprehendida na disposição da mesma que proíbe o recurso de revista às cauzas que cabem na alçada da Relação. He quanto esta junta tem a levar ao conhecimento de Vossa Magesdtade Imperial, sobre o que Vossa Mag.e Imperial Mandará o q. melhor lhe parecer. Deos g.de a Pessoa de V. Mag.e por muitos annos. Angra em sessão de 30 de Março de $1832=o$ Dez.or Prezid.te José António Ferr. ${ }^{\circ}$ Braklami $=o$ Dez.or José Leandro da silva Souza $=$ José das Neves Mascarenhas Mello = Pedro da Fonseca Serrão Velloso = José Pereira Leite Pitta d'Ortigr ${ }^{\circ}$ Negrão $=$ Franc. ${ }^{\circ}$ Jeronimo Coelho e Sousa $=$ Ant ${ }^{\circ}$ Bern. do da costa Cabral, copiado com data de 31 de Março de 1832, fls. 57 e 57v.

${ }^{43}$ Relativamente à apelação interposta por réus condenados em pena corporal maior, cfr. arts. $66^{\circ}, 67^{\circ} \mathrm{e}$ $68^{\circ}$ do Decreto n. $^{\circ} 17$, de 30 de Julho de 1830. 
caso dos livramentos ordinários remetidos à Junta, os juízes de primeira instância que tinham preparado os processos, somente seriam admitidos a votar na sentença, quando de outra forma se não pudesse preencher o número de juízes que a lei requeresse (art. $4^{\circ}$ do Decreto de 27 de Março de 1830).

2. Ao aplicar a letra da Lei de 1830, e tendo por base cerca de uma dezena de processos-crime que tramitaram nesta instância, verificamos que a Junta de Justiça passaria a usar na Ilha Terceira de toda a jurisdição criminal, que pelo Alvará de 15 de Novembro de 1810 havia sido concedido à Junta da Justiça Criminal das ilhas dos Açores ${ }^{44} \mathrm{e}$ em tudo o que não fosse contrário à disposição do Decreto de 27 de Março $\left(\text { art. } 2^{\circ}\right)^{45}$. De igual modo entendia a Secretaria de Estado que deveria ser aplicado o Decreto de 30 de Junho de 1830 , sempre que se tratasse de matéria criminal ${ }^{46}$.

${ }^{44}$ Vide ainda no mesmo manuscrito a cópia dos Decretos n. ${ }^{\circ}$ s 18 e 19 de 24 de Janeiro de 1829 que mandam submeter à Relação de Angra a Junta Criminal criada pelo Alvará de 15 de Novembro de 1810, a fls. $6 \mathrm{v}-7 \mathrm{v}$. Vide nota 15 .

${ }^{45} \mathrm{Vd}$. no mesmo manuscrito a cópia do aviso da Secretaria de Estado enviado à Junta de Justiça a respeito do processo-crime de António Ferreira da Costa (fls. 23-23v) e a resposta da Junta (fls. 23v-25). Sobre a competência criminal, vd. docs. de fls. 14-14v; cópia de uma Portaria datada de 23 de Outubro de 1830 acerca do $\$ 42$ do Decreto de 30 de Junho de 1830 (fls.25-25v), as representações de que trata a portaria (fls. 25v-26), a respectiva resposta da Junta (fl.. 26-28); algumas questões judiciais em trâmite sobre matéria criminal (fls. 32v., 43-45) e ainda a Portaria de 24 de Julho de 1830; o Aviso de 10 de Janeiro de 1831 que dá forma à execução dos réus condenados (fls. 35-35v.);o Aviso a respeito dos réus António Vicente, Henrique José e Julião Vieira, de 25 de Maio de 1831 (fls. 45);o registo de um ofício da Junta de Justiça acerca do réu Manuel Gonçalves Pires, de 1 de Julho de 1831 (fls. 45v-46) e a Portaria a respeito de um requerimento do réu António Silveira Mathias que se encontrava preso na cadeia de Angra, o qual é seguido da informação da Junta (fls. 47v-48). Vide também os docs. de fls. 49v-51 e $55 \mathrm{v}-56$, o primeiro em relação a um recurso de apelação para a Relação de Lisboa interposto pelo réu José Manuel da Costa e o segundo a respeito de um requerimento apresentado pelo Padre António de Faria Pinheiro que estava preso na cadeia de Angra. A fls. 57, é interposto recurso de revista por João d'Ávila no âmbito do processo de injúria que move a João Pacheco.

Vide no mesmo sentido a Portaria de 28 de Julho de 1831, a qual determinava que havendo empate de votos na decisão e embargos opostos à sentença quando um réu for condenado à pena de morte natural e não houver mais dois bacharéis que assistam à disputa judicial, para poderem ser convocados para o desempate, deveria a Junta de Justiça usar de toda a jurisdição criminal concedida pelo Alvará de 15 de Novembro de 1810 à Junta então criada, cabendo ao presidente da Junta proceder ao voto de desempate quando na terra não haja mais quem possa ser chamado, não podendo, contudo, ser chamados para o desempate os bacharéis presentes, por não terem assistido à disputa judicial, nem ouvido os depoimentos das testemunhas.

Vide ainda o aviso de 10 de Janeiro de 1831, cuja cópia se encontra a fls. 35-35, sobre a forma de execução dos réus condenados a pena última.

A respeito da aplicação de pena de morte natural, é trasladado para o presente manuscrito um aviso da Secretaria de Estado, datado de 30 de Setembro de 1830, relativo ao réu António Ferreira da Costa; assim como algumas peças processuais constantes do mesmo processo-crime (fls. 23-25). Vide ainda sobre a figura do executor das penas e a forma de execução dos réus condenados a pena última, doc. de fls. 35-35v. de 10 de Janeiro de 1831. Sobre a aplicação de penas pecuniárias, vide doc. de fls. 35v-36v. de 10 de Janeiro de 1831.

${ }^{46}$ Vide doc. de fls. 18v-20. 
Caso se tratasse de sentenças por morte natural e civil, estas não seriam executadas sem antes serem levadas à presença da Regência pela Secretaria de Estado (art. $9^{\circ}$ do Decreto de 27 de Março de 1830) ${ }^{47}$.

Na sequência do Decreto de 27 de Março de 1830, o Aviso de 9 de Julho do mesmo ano daria a conhecer à mesma Junta a ordem de juízo que deveria ser seguida em virtude da punição dos maos, a segurança dos bons, a tranquilidade pública, a reputação dos magistrados, e a força das leis, tudo depende [r] da exactidão, e inteligência, com que é guardada a ordem do juizo; e quando esta se estabelece de novo, dos Magistrados, a quem se confia o seu estabelecimento, depende o crédito ou descrédito da instituição $o^{48}$.

Para os feitos crimes que deveriam ser processados perante os juízes letrados territoriais nos termos do art. $1^{\circ}$, era guardada a mesma ordem do juízo já estabelecida no diploma de 30 de Julho de 1830, fazendo o juiz territorial as vezes da Junta de Justiça e exercendo o promotor de justiça as atribuições do procurador régio (art. $64^{\circ}$ do Decreto n. ${ }^{\circ} 17$, de 30 de Julho de 1830).

Quando na Junta de Justiça fosse achado no grau de apelação que o julgador da $1^{\mathrm{a}}$ instância deixara de guardar alguma ordenação, ou lei do reino, a mesma Junta deveria aplicar a regra constante no livro I, tit. $5^{\circ}, \S 4$ das OF.

Sempre que a Junta de Justiça devesse, em conformidade com o ordenado nos arts. $12^{\circ}$ e $13^{\circ}$ do Decreto de 30 de Junho de 1830 , proceder à reforma ou ratificação da pronúncia feita pelos juizes da querela, devassa ou sumário, e não estando declarada a ordem que se deve guardar neste importante acto de processo, manda a Re-

\footnotetext{
${ }^{47}$ Nos termos da Portaria de 7 de Janeiro de 1831, o executor das penas de degredo [nos termos do Decreto de 18 de Dezembro de 1830] e pecuniárias julgadas pela Junta de Justiça, existindo na ilha Terceira um presídio onde estão reunidos os réus empregados nos mesmos trabalhos para ele devem ser remetidos aqueles acompanhados da competente guia assinada pelo membro da Junta de Justiça que foi interrogante na disputa do feito, na qual se declarará expressamente que três anos de trabalhos equivalerão a cinco do degredo a que os réus foram condenados. (...) Para a execução das penas pecuniárias deve logo que a condenação passar em julgado ser remetida certidão dela à comissão encarregada da administração da fazenda Pública, para esta fazer cobrar a pena pelo juízo da executória da mesma fazenda. A execução pelas custas deve ser feita pelo juiz da terra onde era o domicílio, ou onde estiverem situados bens do réu condenado, sendo para isso passada carta executória assinada também pelo membro da junta de justiça que foi interrogantes. Sobre os réus pronunciados e condenados a degredo perpétuo e às galés, $v d$ doc. de fls. $38 \mathrm{v}$. Sobre a forma de livramento de réus, vide doc de fls. 20 e o requerimento de Francisco Nunes que se encontrava preso em S. Miguel, a fls. 29v-31, com data de 30 de Junho de 1831.

${ }^{48}$ In Collecção de Decretos e Regulamentos publicados durante o governo da Regência do Reino estabelecida na Ilha Terceira desde 15 de Junho de 1829 até 28 de Fevereiro de 1832, primeira série, Imprensa Nacional, Lisboa, 1836, fls. 38-40.

Recorde-se a este respeito que em 11 de Abril de 1829, uma Portaria da Junta Provisória havia determinado a cessação da suspensão do habeas corpus, restituindo os direitos individuais a todos os cidadãos com a excepção dos crimes de rebelião e traição formal ficando em plena execução o art. $145^{\circ}$ da Carta, cuja cópia se encontra a fls. 8.
} 
gência, em nome da rainha que a reforma, ou ratificação da pronúncia seja sempre feita em audiência pública, depois de lidos em voz alta os autos da querela, devassa ou sumário, os ditos das testemunhas, os interrogatórios e respostas dos réus, se os tiver havido, e quaisquer documentos que acompanham os autos; e que em acto contínuo se siga a ratificação, ou reforma da pronúncia; podendo porém os juizes para conferir sobre ela, retirar-se para outra sala, ou mandar despejar a sala de audiencia enquanto a conferência durar. $O$ dia desta audiência será intimado aos réus, ao menos com a antecipação de 24 horas, e com igual espaço anunciado ao público por edital afixado na porta exterior da casa da audiência (ex vi do disposto no Decreto n. ${ }^{\circ} 18$, de 2 de Agosto de 1830).

2. Muito embora os recursos interpostos tenham sido quase que exclusivamente do foro criminal, não podemos ignorar o caso único do pedido de suspensão de arrematação de bens, ainda que o mesmo não apresente quaisquer aspectos relevantes ${ }^{49}$.

3. A Junta de Justiça podia ainda conhecer e decidir em última instância de matérias atinentes à Fazenda Pública, devendo ouvir por escrito o procurador da fazenda em todos os casos em que conforme a Direito, é necessária a sua assistência ou intervenção e enquanto durassem as já mencionadas circunstâncias políticas que haviam conduzido à criação deste tribunal ${ }^{50}$.

\section{e. Continuação}

1. Tal como decorre nos demais tribunais de segunda instância, também era reconhecida competência à Junta de Justiça para conhecer das devassas e residências efectuadas aos magistrados e funcionários judiciais em exercício de funções no arquipélago dos Açores, conforme decorre do exposto no Decreto de 30 de Junho de $1831^{51}$.

Muito embora o entendimento não pareça suscitar dúvidas, os desembargadores viriam a decidir na sessão de 14 de Outubro de 1831 que no caso dos escrivães da ilha do Pico (José Francisco Zuzarte e José Inácio da Silveira) que tinham servido com o bacharel José Prudêncio Telles ${ }^{52}$ e que viriam a ser pronunciados após ter sido

\footnotetext{
${ }^{49}$ Trata-se do pedido de suspensão de arrematação de bens apresentado por D. Rita Plácida, cfr. doc. de fls. $55 \mathrm{v}-56$.

${ }^{50}$ Cfr. Decreto n. ${ }^{\circ}$ 9, de 1 de Abril de 1830 e doc. de fls. 17-18.

${ }^{51}$ Vide documento de fls. 52v-54. A fls. 53v-54 encontra-se ainda a cópia de uma Portaria de 19 de Dezembro de 1831, a respeito desta mesma matéria que vem determinar que o membro da Junta a quem fosse distribuída a devassa em questão deveria exercer as atribuições que competissem á vara do crime, nos termos do Decreto de 30 de junho de 1831

${ }^{52}$ José Prudêncio Telles de UTRA MACHADO Açoreano (Horta, Faial, 1804-?-?). Filho de José Telles de Utra Machado e neto de Estácio Machado d'Utra Telles e de D. Marianna Telles, naturais da Horta, não se declara as filiaçoens maternas por ser filho de huma senhora ingognita (in Iantt, Leitura de Bacharéis, 1826, maço 80, n. ${ }^{\circ} 32$ ). Nos anos lectivos de 1823-1824 e 1825-1826, o seu nome consta do rol de alunos inscritos, respectivamente, nos $3^{\circ}$ e $5^{\circ}$ ano do Curso de Leis (vd. Relação e Índice al-
} 
tirada a devassa e residência na vila das Lages, representando ... a Vossa Magestade que sendo costume e prática nas Relações, distribuirrem-se tais devassas do crime, digo, dos actos a uma das varas do crime para nela ser dada a competente pronúncia, e os mais termos necessários, para o andamento legal e lhe serem sentenciados com adjuntos, acontece que nesta junta não existe a necessária decisão das varas para poder (...) esta prática; nem mesmo o decreto de 30 de Junho de 1830 que deu nova forma ao processo-crime concede a faculdade de um só juiz pronunciar ou a mesma junta preenchido necessário numero de seus vogais, mas pelo contrário só autoriza para confirmar ou negar a pronúncia depois de feito prova que resultar da leitura conforme declara o citado decreto no cap. $4^{\circ}, \$ \$ 12$ e 13 nestes termos encontrando a Junta este obstáculo no desempenho dos seus serviços oferece estas reflexões (...) Angra em secção de 14 de Outubro de 1831.

2. Igualmente, dispunha o Decreto n. $^{\circ} 13$, de 2 de Junho de 1830 que estando interrompido o recurso à Mesa do Desembargo do Paço e tendo cessado nesta ilha com a instalação da Regência a Junta a quem competia, em conformidade do alvará de 10 de Setembro de 1811, a decisão de muitos negócios pertencentes ao despacho da mesma mesa (...) deveriam todos os agravos que eram levados desta ilha para a Mesa do Desembargo do Paço ${ }^{53}$ ser doravante do conhecimento da Junta de Justiça onde seriam julgados em última instância $\left(1^{\circ}\right)^{54}$.

phabetico dos estudantes matriculados ...), pp. 19 e 27. Bacharel em Leis (conforme declaração constante do processo de leitura de bacharéis, tendo sido nomeado para a comarca da ilha do Pico, ex vi do Decreto de 9 de Fevereiro de 1829, publicado na Gazeta de Lisboa, n. ${ }^{\circ}$ 38, de 13 de Fevereiro de 1829, p. 151.

${ }^{53}$ Foi criado por D. João II e extinto no alvor do liberalismo pelo Decreto de 3 de Agosto de 1833 tendo as suas atribuições reguladas pelos diplomas de 30 de Maio de 1533, 10 de Outubro de 1534, 2 de Novembro de 1564 e de 20 de Julho de 1586. Não obstante as já enunciadas reformas de D. João III seria contudo Filipe II que lhe outorgaria um novo regimento, em 27 de Julho de 1582 a que se seguiu a Carta Régia de 21 de Agosto de 1607, o Alvará de 30 de Outubro de 1641 e o Alvará de 24 de Julho de 1713 que lhe conferiria capacidade para despachar autonomamente (por provisão) licenças, suplementos de idade, petições de perdão e revistas.

Trata-se de um órgão judicial com atribuições políticas como as que fazem depender de consulta ao monarca da aprovação e revogação de leis, apreciação, aprovação de bulas e breves papais e a concessão de mercês. Em matéria judicial cabia-lhe decidir sobre os conflitos de jurisdição, aconselhar o rei em matéria de perdão nas causas crime, decidir sobre adopções, cartas de doação, conceder dispensas de idade e de nobreza, conceder as cartas de apelação e os alvarás de fiança bem como o perdão dos delitos em certos crimes.

Competia-lhe ainda em matéria judicial despachar as petições de revista (cfr. Lei de 3 de Novembro de 1768) e de graça que [nos] for pedida em causa que à justiça tocar, assim como cartas de privilégio e liberdades [...] (OF, I,3), acrescentando-lhe o Alvará de 7 de Janeiro de 1750 a concessão de cartas de legitimação de fillhos adulterinos, sacrílegos e incestuosos, licenças para espingardas, provisões para os clérigos possuírem bens, provisões de perdão, habilitações dos bacharéis, etc.

A Carta de lei de 19 de Julho de 1790 ao determinar a extinção das ouvidorias e as isenções de correição levaria o legislador do Regulamento de 7 de Janeiro de 1792 a ampliar as competências ao Desembargo do Paço aos territórios dos donatários. 
Por este motivo, pertenciam à mesma Junta de Justiça as nomeações de advogados, guardadas as disposições do alvará de 10 de Setembro de 1811, os provimentos de procuradores, não excedendo o número que estiver determinado; as licenças para os clérigos poderem advogar no foro secular; e as licenças para poderem advogar pessoas que não forem graduadas pela Universidade de Coimbra em alguma das faculdades jurídicas, precedendo os exames e diligências da lei e estilo $\left(2^{\circ}\right)$. Todos os demais assuntos da competência da Mesa do desembargo do paço pertencer[iam] ao imediato conhecimento da regência e ser[iam] expedidos por portarias do Ministro e Secretário de Estado enquanto não fo[ss]em determinadas as regras que se deve[ss]m guardar acerca de cada um delles $\left(3^{\circ}\right)^{55}$.

3. Eram, ainda, abolidos os agravos de injusta pronúncia, e quaisquer outros que até então se tiravam nos feitos crimes perante os juízes da $1^{\mathrm{a}}$ instância. Com esta medida os desembargos e sentenças deste magistrado eram tidos como nenhuns, sendo ainda este último classificado como suspeito em todos os actos em que fossem partes aqueles sujeitos processuais, sendo condenado a pagar vinte cruzados às partes em litígio e suspenso do respectivo ofício.

\section{f. Composição}

O mesmo diploma de 27 de Março de 1830 consagrava no seu art. $1^{\circ}$ a composição deste novo tribunal, a qual previa a nomeação de um presidente e seis vogais extraordinários, sendo estes últimos escolhidos pelo presidente entre os bacharéis residentes na ilha Terceira ${ }^{56}$. A ordem de preferência deveria respeitar os mais graduados e só

Com a extinção da Real Mesa Censória, o Desembargo do Paço permanecerá com as matérias de autoridade régia, numa clara separação entre o domínio secular e eclesiástico (Carta de lei de 17 de Dezembro de 1794).

Já no início do século XIX e por alvará de 22 de Abril de 1808, seria criada no Rio de Janeiro uma nova instituição, designada Mesa do Paço e da Consciência e Ordens, com a incumbência de tratar os assuntos do Desembargo do Paço, Mesa da Consciência e das Ordens e Conselho Ultramarino.

A extinção deste tribunal (ex vi do Decreto de 3 de Agosto de 1833) determinaria que as atribuições de graça do tribunal fossem devolvidas para as respectivas secretarias de Estado e as de administração de Justiça para os juízes competentes.

Dele faziam parte o presidente e um número variável de desembargadores de carreira cuja ascensão e nomeação revelavam uma carreira longa e elogiosa que havia passado pela Casa da Suplicação.

Do seu quadro funcional e a respeito de uma análise mais detalhada das suas atribuições, falaremos mais adiante.

Cfr. a este respeito entre outros, Homem, António Pedro Barbas, Espírito das Instituições e Iudex Perfectus; Subtil, José Manuel Louzada Lopes, O Desembargo do Paço, U.A.L., Lisboa, 1996.

${ }^{54}$ Vide, ainda a este respeito, o Decreto de 1 de Abril de 1830.

${ }^{55}$ In Collecção de Legislação..., fl. 19.

${ }^{56}$ Mais tarde, o Decreto de 27 de Março de 1831 determinaria que os lugares poderiam ser ocupados pelos bacharéis emigrados que se encontrassem nesta mesma ilha. $V d$. ainda a Portaria expedida em consequência de um requerimento do bacharel António do Rego Faria de Barbosa, em relação ao disposto 
depois os que estivessem empregados nos lugares de letras ${ }^{57}$. Decreto de 27 de Julho de 1831, os lugares de letras poderiam passar a ser ocupados pelos bacharéis emigrados que se encontrassem na Ilha Terceira ${ }^{58}$.

Em termos comparativos, o número é assaz reduzido se comparado com o total de magistrados que compunham na mesma altura a Casa da Suplicação ${ }^{59}$, a Relação do Porto ${ }^{60}$ ou mesmo a Relação de Lisboa ${ }^{61}$, nos moldes em que a Carta de Lei de 2 de Novembro de 1822 o consagraria.

Tal como sucedia no continente do Reino, a regra supletiva de provimento de magistrados indicava que nos lugares das novas Relações deveriam ser colocados os ma-

no $§ 1$ do Decreto de 27 de Março de 1830, acerca da nomeação de vogais extraordinários providos por bacharéis residentes nas ilhas, em que é dada preferência aos mais graduados e, em último lugar, aos empregados nos lugares de letras, a fls. 39-40 v.

${ }^{57}$ Acerca da ordem de precedência, cfr. Aviso de 2 de Agosto de 1831. Vide ainda o doc. de fls. 47.

${ }^{58}$ Mais tarde, em 22 de Março de 1831, é expedida uma portaria em consequência de um requerimento apresentado pelo bacharel António do Rego Faria de Barbosa [Barcelos(?-?). Filho de António de Faria Rego Barbosa. No ano lectivo de 1823-1824 encontrava-se matriculado no $4^{\circ}$ ano do curso de Leis na Universidade de Coimbra (vd. Relação e Índice alphabetico dos estudantes matriculados...), p. 23. Desempenhou as funções de juiz de fora na ilha do Pico e de juiz de Direito substituto na Terceira. Exerceu ainda as funções de administrador do concelho de Barcelos (1846), presidente da Câmara da mesma localidade, deputado em várias legislaturas, tendo ainda integrado algumas comissões de Legislação e da Comissão de Verificação de Poderes], em que se dava a conhecer que contrariamente ao disposto no §1 do Decreto de 27 de Março de 1830 que versa sobre a nomeação de vogais extraordinários providos por bacharéis residentes nas ilhas em que se dá a preferência aos mais graduados e em último lugar aos empregados de letras, a Junta de Justiça havia decidido por unanimidade de votos não poderem ser convocados os bacharéis que não fossem graduados, isto é que não tivessem o grau de doutor ou não estivessem habilitados para os lugares de letras(vide doc. de fls. 39-40v.) excluindo desta forma os bacharéis como o Suplicante. A esta exposição a Junta responde que o pedido é totalmente falso, argumentando que julgou suprindo às circunstâncias do foro, a nomeação que mostra o assento compreendendo nela todos os bacharéis que se mostraram habilitados(???) de fazer excepções que de contrário são odiosas, deixou aos advogados provisionários a livre faculdade de procurar nos auditórios dos juizos de primeira instância. À vista do exposto, parece que a junta de justiça em o sobredito assunto conformando-se como o fez com o interesse público não deu motivo legítimo à queixa do suplicante.

O Aviso de 2 de Agosto de 1831 determinaria, novamente, as regras de precedência dos magistrados da Junta de Justiça declarando que se deveria seguir em primeiro lugar a maior graduação e depois a antiguidade no serviço da magistratura.

${ }^{59}$ A Casa da Suplicação reunia nos seus quadros um total de dez desembargadores dos agravos e apelações, quinze desembargadores extravagantes, dois corregedores do crime, dois do cível, um chanceler, um juiz de chancelaria, dois juízes da Coroa e Fazenda, quatro ouvidores das apelações do crime, um juiz de chancelaria, um procurador da fazenda, um da coroa e um promotor de justiças (O.F., 1.5, proémio).

${ }^{60}$ A Relação do Porto era composta por um chanceler, um corregedor do crime, um corregedor do cível, um juiz dos feitos da Coroa, três ouvidores do crime, um juiz da chancelaria, um promotor de justiça, seis desembargadores extravagantes e um procurador da Coroa (O.F., 1, 35,3).

${ }^{61}$ A letra da Carta de lei de 2 de Novembro de 1822 atribuía à Relação de Lisboa um total de quinze desembargadores; à do Porto, doze e dez para os casos das Relações de Mirandela, Viseu e Beja. Cada uma das mencionadas Relações disporia ainda de um presidente, um procurador da soberania nacional e da coroa, um procurador da fazenda, um promotor de justiças, um solicitador, um tesoureiro, um guarda-mor um guarda-mor e um guarda-menor (art. $3^{\circ}$ ). 
gistrados que maiores provas tivessem dado de virtudes, conhecimentos e adesão ao sistema constitucional, sendo dada, entre estes, a preferência, aos que já tivessem servido na Casa da Suplicação, ou da Relação do Porto, ou em alguma das Relações do Ultramar, donde tivessem vindo legalmente; e, em seguida, aos que tivessem servido por mais tempo fora das Relações (art. 13 da Carta de lei de 2 de Novembro de 1822).

Recorde-se que nos primeiros anos da monarquia constitucional ora se impôs, ora se afastou a necessidade do exame da leitura no Desembargo do Paço como requisito para o ingresso na magistratura ${ }^{62}$.

As particularidades da Junta determinavam então que a selecção de juízes fosse da responsabilidade do seu presidente, não dependendo também, ao contrário do que ocorria no continente que estes provimentos fossem feitos por proposta do Conselho de Estado, a qual era apresentada em listas simples, permitindo ao Governo rejeitar uma e mandar proceder a nova proposta ${ }^{63}$.

Na mesma data de 27 de Março de $1830^{64}$ é promulgado um outro decreto que determina que caberá à Regência nomear para presidente da Junta de Justiça, o Dr. João José da Cunha Ferraz ${ }^{65}$ do Conselho de Sua Magestade e para membros, o Dr. Luis Ribeiro de Sousa Saraiva ${ }^{66}$, o bacharel Francisco Magalhães Coutinho ${ }^{67}$, que servirá de auditor da guarnição daquela ilha, o bacharel Pedro da Fonseca Serrão Veloso ${ }^{68}$, e o bacharel José Pereira Leite Pitta Negrão ${ }^{69}$, os quais servirão na sobredita Junta de Justiça enquanto a Regência o houver por bem ${ }^{70}$. A estes membros se associará o nome

\footnotetext{
${ }^{62}$ Cfr. os Decretos de 8 de Maio de 1821 e de 30 de Setembro de 1823 e a Lei de 6 de Agosto de 1822 .

${ }^{63} \mathrm{Vd}$ ainda o art. $13^{\circ}$ da Carta de lei de 2 de Novembro de 1822 e o art. 123\%/III da Constituição de 1822. Saliente-se ainda que na Carta Constitucional, o acto de nomear os magistrados é atribuído ao Poder Executivo, na pessoa do monarca, enquanto chefe do mesmo (art. $75^{\circ} \S 3$ do art. $12^{\circ}$ do Decreto n. ${ }^{\circ} 24$, de 16 de Maio de 1832), ao passo que o poder de os suspender constitui um acto do Poder Moderador $\left(\right.$ art. $\left.74^{\circ} \S 6\right)$.

${ }^{64}$ Vide doc. de fls. $16 \mathrm{v}-17$.

${ }^{65}$ Vide nota 17.

${ }^{66}$ Vide nota 18.

${ }^{67}$ Francisco Magalhães COUTINHO, filho de Luis de Magalhães, natural de Castelo de Ferreira, comarca de Viseu (vd. Relação e Índice alphabetico dos estudantes matriculados na Universidade de Coimbra no Anno lectivo de 1814-1815, p. 29). No ano lectivo de 1814-1815, o seu nome consta do rol de alunos matriculados no $5^{\circ}$ ano do Curso de Leis. Mais tarde exercerá as funções de juiz de fora e desembargador da Relação de Lisboa (cfr. Iantt, MNEJ, maço 406/15).

${ }^{68}$ Vide nota 23.

${ }^{69}$ Vide nota 25.

${ }^{70}$ Fundado nos preceitos constantes das Ordenações Filipinas, é reconhecida aos juízes das Relações a possibilidade de conhecerem em grau de recurso das decisões de $1^{\mathrm{a}}$ instância, bem como analisarem o expediente de negócios de graça ou mercê, a atribuição de cartas de perdão ou comutação de penas aos criminosos e ainda a resolução de todas as petições feitas ao rei, com excepção das que dissessem respeito ao património da Coroa ou da fazenda Pública, a feitos crimes, alheios à sua jurisdição e às obras e contas dos concelhos. Cabia-lhes, ainda, prover sobre a confirmação de eleições de juízes, perfilhamentos, doações entre particulares, e, a concessão de cartas de privilégio, legitimação, restituição de fama, habilitações e quaisquer outras mercês semelhantes (OF, 1,3).
} 
dos bacharéis José das Neves Mascarenhas e Melo ${ }^{71}$, Matheus António Pereira da Silva $^{72}$ e António Bernardo da Costa Cabral ${ }^{73}$, segundo termo de nomeação respectivamente de 15 de Julho de $1831^{74}, 1$ de Agosto de $1831^{75}$ e de 5 de Janeiro de $1832^{76}$.

Em 21 de Abril de 1832, por altura da sua extinção, compunham este tribunal: José António Ferreira Braklami ${ }^{77}$, na qualidade de desembargador presidente e os de-

${ }^{71}$ José das Neves MASCARENHAS e MELO (Tromelgo, concelho da Figueira da Foz, 1787- ?). Filho de Anselmo José das Neves e de Ana Joaquina Mascarenhas. Bacharel em Cânones e em Leis (1813), juiz de fora em Penela (1818), Penafiel (1825), juiz do crime em Coimbra (1822) e desembargador da Relação do Porto e meirinho da Casa da Suplicação (vd. Iantt, MNEJ, maço 574/1) e conselheiro do STJ (vd. Iantt, maço 706(4). Foi eleito deputado (1822-23, 1834-36) e exerceu ainda as funções de capitão da Companhia de Ordenanças da Figueira da Foz. No ano lectivo de 1804-1805 esteve matriculado em Retórica, conforme Relação e Índice alphabetico dos estudantes matriculados na Universidade de Coimbra no Anno lectivo de 1804-1805, suas naturalidades, filiações e moradas, p. 48. Já nos anos lectivos de 1811-1812 e 1812-1813, o seu nome consta do rol de alunos inscritos respectivamente nos $4^{\circ}$ e $5^{\circ}$ anos do curso de Leis, conforme Relação e Índice ..., pp. 13 e 15.

A 2 de Novembro de 1829 entrou na Torre de S. Julião da Barra, tendo sido condenado, em 16 de Novembro de 1829, ao desterro por dez anos para Angola (cfr. Lopes, João Baptista da Silva, História dos presos de S. Julião da Barra, Publicações Europa América, Mem-Martins, s/d, p. 67).

${ }^{72}$ Mateus António Pereira da SILVA. É sendo natural de Vila Real de Santo António (1788) (vd. Relação e Índice alphabetico...) sendo filho de Agostinho Pereira da Silva e de D. Maria Salerique, neto paterno de António Pereira da Silva e de D. Thereza da Encarnação, naturais de Lamego; e neto materno de António Salerique e de D. Francisca Mestre naturais de Vila Real de Santo António (in Iantt, Leitura de Bacharéis, 1815, maço 58, n. ${ }^{\circ} 23$ ). Desconhece-se o local da sua morte. Nos anos lectivos de 1808$1809,1811-1812,1812-1813$ e 1813-1814,o seu nome consta do rol de alunos matriculados respectivamente nos $1^{\circ}, 3^{\circ}, 4^{\circ}$ e $5^{\circ}$ anos do curso de Cânones, conforme Relação e Índice alphabetico.., pp. 5, 8, 4 e 9.Bacharel em Cânones, juiz de fora de Lagos (1823), recebedor-geral em Angra (1833) e depois da Província Oriental dos Açores, deputado pelo Algarve (1846).

Acerca do auto de nomeação deste magistrado para membro da Junta de Justiça datado de 1 de Agosto de 1831, vide doc. de fls. 46v.

${ }^{73}$ António Bernardo da Costa CABRAL, $1^{\circ}$ Conde e $1^{\circ}$ Marquês de Tomar (1803-1889). Filho de António Bernardo da Silva Cabral e de Francisca Vitória Rebelo da Costa Corte Real. Bacharel em Direito, advogado e juiz de fora, membro do Supremo Tribunal de Guerra, auditor geral do exército durante o governo de D. Pedro. Desempenhou as funções de Procurador Régio na Relação do Porto (1832-34), juiz da Relação dos Açores (1834), deputado, Ministro dos Negócios Eclesiásticos de Justiça, Conselheiro de Estado, Par do Reino e embaixador de Portugal em Madrid após o episódio político conhecido por Maria da Fonte.

${ }^{74}$ Vide doc. de fls. 46.

${ }^{75}$ Vide doc. de fls. 46v.

${ }^{76}$ A fls. 54.

77 José António Ferreira BRAKLAMI (Lagos, 1780-1847). Bacharel em Leis pela Universidade de Coimbra. Desempenhou as funções de juiz de fora (1806), corregedor, desembargador e ouvidor das Alagoas (1823), da Relação do Porto (1826), Lisboa (1834) e juiz conselheiro do STJ (1839). Com o regresso de D. Miguel a Portugal, em 1828, exila-se nos Açores, vindo a ser nomeado juiz da Relação. Após ter sido instalado o Conselho da Regência na Ilha Terceira, foi nomeado ministro e secretário de estado de todas as pastas (Reino, Negócios Eclesiásticos e Justiça, Fazenda e Estrangeiros), à excepção da de Guerra e Marinha, entre 2 de Julho e 10 de Outubro de 1831. Em 19 de Novembro 1834 seria nomeado juiz da Relação de Lisboa. Foi ainda eleito deputado nas legislaturas de 1822-23, 1826-28, 1834-36 e 1840-42. 
sembargadores José Leandro da Silva Souza ${ }^{78}$, José das Neves Mascarenhas Mello ${ }^{79}$, Pedro da Fonseca Serrão Velloso, José Pereira Leite Pitta d'Ortigueira Negrão, Francisco Jerónimo Coelho e Sousa ${ }^{80}$ e António Bernardo da Costa Cabral.

\section{g. O presidente da Junta de Justiça}

Nas funções de presidente da Junta, a João José da Cunha Ferraz sucede o desembargador José António Braklami nomeado pelo Decreto de 7 de Maio de $1831^{81}$, cargo para o qual foi renomeado nos termos do Decreto 31 de Outubro de $1831^{82}$.

O presidente da Junta de Justiça exerceria as funções de chanceler e de contador devendo proceder à distribuição dos feitos nos termos dos arts. $5^{\circ}$ e $7^{\circ}$ do Decreto de 27 de Março de $1830^{83}$.

De igual modo, o Decreto n. ${ }^{\circ} 41$, de 21 de Julho de 1831 dispunha que para

evitar os inconvenientes, que se seguem de não haver na Junta de Justiça, no caso de empate, quem tenha assistido à disputa judicial dos feitos, para poder desempatar, a Regência depois de ouvir a Junta consultiva, determinou que o presidente da junta de justiça, quando o julgar conveniente, possa convocar para assistirem à disputa judicial, além do número de juizes requeridos pela lei, mais dois juizes extraordinários, para votarem no caso de empate, ou para algum deles suprir, caso de impedimento, ou falta de algum dos outros juizes ${ }^{84}$.

\footnotetext{
${ }^{78}$ José Leandro da Silva SOUZA (Coimbra, 1781-Caldas da Rainha, 1834). Filho de Camilo José da Silva Nunes (desembargador da Relação e Casa do Porto) e de Teresa Inácia de Sousa Lobo, neto paterno de José Pereira e de D. Josefa da Silva, naturais de S. João da Pesqueira, comarca de Trancoso e, pela parte materna, de António Gonçalves e de D. Maria Joana de Sousa Lobo, de Coimbra (in Iantt, leitura de bacharéis, 1804, maço 68, n. $\left.{ }^{\circ} 29\right)$. No ano lectivo de 1802-1803 encontrava-se matriculado no $5^{\circ}$ ano do Curso de Leis, conforme Relação e Índice alphabetico dos estudantes matriculados na ..., p. 34. Desempenhou as funções de juiz de fora na ilha das Flores (1807), ouvidor em cabo Verde (1811), desembargador da Relação da Baía e do Maranhão (1819), desembargador do Tribunal da Relação do Porto (1824), membro da Junta de Justiça em Angra (1830), presidente do Tribunal da Relação dos Açores (1832), conselheiro e vice presidente do STJ (1833).

${ }^{79}$ Cfr. auto de nomeação para membro da Junta, datado de 15 de Julho de 1831, a fls. 46.

${ }^{80}$ Francisco Jerónimo COELHO e SOUSA (Santa Cruz da Graciosa, 1802-Fajã de Baixo, 1888). Filho de Fructuoso José Coelho. No ano lectivo de 1823-1824, o seu nome consta do rol de alunos inscritos no $4^{\circ}$ ano do Curso de Leis da Universidade de Coimbra (vd. Relação e Índice alphabetico dos estudantes matriculados ...), p. 21. Bacharel em Leis (1825) Juiz de fora da Graciosa, juiz de direito da comarca Ocidental da Madeira, desembargador da Relação dos Açores (1861) e presidente da mesma (1872). Deputado pelo círculo eleitoral dos Açores nas legislaturas de 1840-42 e 1842-45.

${ }^{81}$ Vide doc. de fls. 40v-41.

${ }^{82}$ Vide doc. de fls. $48 \mathrm{v}-49$.

${ }^{83} \mathrm{Cfr}$. a respeito da figura do presidente dos tribunais de segunda instância, o disposto no art. $7^{\circ}$ da Carta de Lei de 2 de Novembro de 1822.

${ }^{84}$ No mesmo sentido vd. o Decreto de 28 de Junho de 1831.
} 


\section{h. O escrivão}

Indicados os magistrados, cabe uma palavra para os funcionários judiciais que os coadjuvavam no exercício judicial, em especial, o escrivão.

Foram escrivães da Junta de Justiça, os funcionários Luís António Pires Forte e Vicente Pereira de $\mathrm{Matos}^{85}$, os quais eram, também, os escrivães da correição de Angra, em conformidade com o disposto no art. $6^{\circ}$ do Decreto de 27 de Março de $1830^{86}$.

Muito embora o texto nada especifique em particular, as regras que regiam supletivamente o provimento de lugares de escrivão impunham a verificação da nacionalidade portuguesa, maioridade de vinte e cinco anos, a não inibição da administração dos bens de que se poderia ser proprietário; a dignidade por talentos e virtudes assim como saber ler e escrever correctamente (OF, I, 12.1; 14-16; 58.3). Do escrivão dizia ainda Pereira e Sousa ${ }^{87}$ não poder ser o furioso, o demente, o pródigo a quem havia sido proibida a administração dos seus bens, a mulher e o infame. Deveria ainda ser juramentado (OF. 1, 24), entendido, expedito e exacto, devendo guardar os processos para deles dar conta a todo o tempo (OF., $1,1,31 ; 1,24.25)^{88}$

\section{i. O Procurador da Coroa}

Identificados e caracterizados os magistrados e funcionários judiciais que compuseram a Junta de Justiça durante o biénio do seu funcionamento, importa dedicar algumas palavras à figura do procurador da coroa que nela exerceu funções. Para o desempenho destas funções foi nomeado pela Regência ${ }^{89} \mathrm{o}$ bacharel Manuel Joaquim Nogueira ${ }^{90}$, conforme termo de juramento datado de 14 de Julho de $1830^{91}$. No cum-

\footnotetext{
${ }^{85}$ Cfr. doc. de 24 de Dezembro de 1830, a fls. 34-35.

${ }^{86}$ Sobre o pedido de ordenado apresentado pelos escrivães da Junta, vide doc. emitido pela Junta datado de 10 de Janeiro de 1831, de fls. 34-35.

${ }^{87}$ In Sousa, Joaquim José Caetano Pereira e, Primeiras linhas sobre o processo civil, I vol., Imprensa Nacional, Lisboa, 1834, § LXXIV

${ }^{88}$ Muito embora não existam documentos esclarecedores quanto aos funcionários judiciais, entendemos que seriam aplicadas as mesmas regras que eram adoptadas nos demais tribunais e que por analogia, com o que havia estado consagrado para a Relação de Angra. A fls. 28v., com data de 12 de Novembro de 1830, encontra-se uma informação sobre a gratificação que é conferida a Anacleto José de S (?) enquanto porteiro da Junta de Justiça.
}

${ }^{89}$ Vide doc. de fls. 20v.

${ }^{90}$ Manuel Joaquim NOGUEIRA (Tomar, 5 de Novembro de 1787 - Caldas da Rainha, 2 de Janeiro de 1862), militar, conselheiro de Estado, comendador da Ordem de Nossa Senhora da Conceição de Vila Viçosa, fidalgo e Cavaleiro da Casa Real. Era filho de Agostinho José Nunes, natural de Tomar, e de D. Maria Rosa Nogueira (in Relação e Indice alphabético dos estudantes matriculados na Univerfidade de Coimbra no anno lectivo de 1808 para 1809; fuas naturalidades, filiações, e moradas, p. 16, n. ${ }^{\circ} 39$, é aluno do quarto ano de Cânones) em 1808, quando Portugal foi invadido pelo exército francês, vindo a alistar-se no Batalhão de Voluntários Académicos, passando para a primeira linha como alferes até 1813 , em que pediu a demissão para completar a sua formatura, foi condecorado com a Cruz de Ouro da Guerra Peninsular, e com a da Batalha de Albufeira a que assistiu. Desempenharia as funções 
primento das suas atribuições, cabia-lhe seguir os termos da acusação de todos os crimes que nela fossem julgados e em que tivesse lugar a justiça assim como promover à execução das condenações. As demais atribuições, bem como o predicamento e o ordenado deste procurador régio seriam marcados por decreto especial (art. $2^{\circ}$ do Decreto n. ${ }^{\circ} 17$, de 30 de Julho de 1830).

\section{j. Os advogados junto da Junta de Justiça}

Em 23 de Agosto de 1830, na presença de Cunha Ferraz e Serrão Veloso, é apresentada a proposta de nomeação de alguns bacharéis para exercerem as funções de causídicos junto da mesma Junta. A presente proposta fundamentava-se no disposto do Livro I, tit. 48, §21 e do Livro III, tit. 19, §2 das Ordenações Filipinas, bem como nos Assentos de 2 de Maio de 1654 e de 24 de Março de 1672.

Os nomes indicados são: Manuel Joaquim Nogueira, Raimundo José de S., João Silveira da Cunha, António Gravito92, António José Pereira Leite e Manuel da Cunha Paredes ${ }^{93}$. Para procuradores são referidos os nomes de António Inácio Parreira, Gonçalo José Gomes da Mata, Francisco de Melo Ribeiro e António de Carvalho Sousa ${ }^{94}$.

Estando determinado o número de advogados com licença para advogar junto da Junta de Justiça em cumprimento das regras constantes do disposto nas OF, III, 19, § $2^{95}$, decidia a Junta de Justiça, em assento tomado na sessão de 17 de Novembro de 1830 que

de advogado em Tomar, até 1823, data em que parte para Angra, vindo a participar na revolta de 22 de Junho de 1828. Mais tarde, e sempre na qualidade de apoiante de D. Pedro e de D. Maria II, seria nomeado juiz da Relação de Angra.

${ }^{91}$ A fls. 20v.-21. Cfr. art. $4^{\circ}$ do Decreto n. ${ }^{\circ} 17$, de 30 de Julho de 1830.

Como os próprios diplomas o referiam, tratava-se do exercício de uma comissão do poder executivo, sendo assim um cargo de natureza amovível. Pelo Aviso de 5 de Maio de 1831, sendo o ministério do procurador régio uma comissão do poder executivo, essencialmente dependente, e imediatamente sujeita a ele, é do mesmo poder executivo que o procurador régio deve receber, e a quem deve pedir as instruções e providências que os casos ocorrentes mostrarem ser necessárias dirigindo-se para esse fim directamente pela secretaria de estado e repartição dos negócios de justiça sem intervenção do presidente da Junta, o qual, por pertencer a um poder de diversa natureza não pode ser intermédio entre o governo e os seus agentes.

${ }^{92}$ António Barreto Ferreira GRAVITO, juiz de fora da ilha do Pico ex vi do Decreto de 9 de Fevereiro de 1829, publicado na Gazeta de Lisboa, n. ${ }^{\circ} 38$, de 13 de Fevereiro de 1829.

${ }^{93}$ Manuel da Cunha PAREDES (Viseu, 1802 - Lisboa, 1884). Filho de José da Cunha Paredes. Nos anos lectivos de $1825-1826,1826-1827$ e $1817-1828$, esteve matriculado nos $3^{\circ}, 4^{\circ}$ e $5^{\circ}$ anos do Curso de Leis, conforme informação constante dos respectivos índices (Relação e Índice alphabetico dos ..., pp. 22, 26 e 33). Bacharel em Leis (1828). Desempenhou as funções de promotor de justiça em Angra (1831-1833), juiz dos órfãos (1834-1835) e conselheiro do STJ. Exerceu ainda as funções de governador civil interino de Lisboa (1868), deputado (1853-56 e 1857-58).

${ }^{94}$ Vide docs. de fls. 21-22.

${ }^{95}$ Cfr. fls. $22 \mathrm{v}-23$. 
... estando em junta os ministros abaixo assinados, o Senhor Doutor João José da Cunha Ferraz, do conselho de Sua Magestade, o presidente e chanceler do mesmo, ahi por unanimidade de votos foi deliberado $=$ que visto acharem-se impedidos alguns bacharéis nomeados para advogados da Junta e que não havendo outros em iguais circunstâncias nomeavam para substituir aos provisionais Francisco Lúcio Duarte Reis ${ }^{96}$, André Avelino Homem da Costa Noronha e Nemésio Damásio da Costa Silva. ${ }^{97}$

\section{k. Dissolução ( O Decreto de 20 de Maio de 1832)}

A fls. 59, com data de 24 de Maio de 1832, era trasladado para o manuscrito existente na Junta de Justiça de Angra, o seguinte decreto com data de 20 do mesmo mês

manda o duque de Bragança, regente em nome da rainha transmitir a $\mathrm{V}$. M.ce a copia inclusa do decreto desta data a fim de que fazendo presente á Junta Suprema de Justiça esta fique na inteligência do seu conteúdo e lhe dê execução. Deus guarde V. magestade. Paço em Ponta Delgada, 20 de Maio de 1832. José Xavier Mouzinho da Silveira $=$ senhor Desembargador Presidente da Junta Suprema de Justiça = cumpra-se e registe-se, Angra 24 de Maio de 1832 = Braklami= tendo acabado as circunstâncias que fizerão necessária a criação de uma Junta suprema de Justiça na cidade de Angra por decreto de 27 de Março de 1830 : Hei por bem em nome da Rainha, dissolver a sobredita Junta declarando aos membros dela que a satisfação e o acerto em que se houverão no exercício de suas funções os torna dignos da estima pública e da consideração do Governo. O Ministro e Secretario d'Estado dos negócios de Justiça o tenha assim entendido e faça para a sua execução as participações necessárias. Paço em Ponta Delgada, 20 de Maio de 1832 - Dom Pedro Duque de Bragança - José Xavier Mouzinho da Silveira - está conforme - Secretaria d'Estado dos Negócios de Justiça em Ponta Delgada 20 de Maio de $1832=$ Bartholomeu dos Mártyres Dias e Souza.

Cumpridos os objectivos a que se destinara, a extinção da Junta de Justiça apresentava-se assim como a consequência imediata do disposto no art. $272^{\circ}$ do Decreto n. ${ }^{\circ}$ 24, de 16 de Maio de 1832, que constituía o diploma da reforma judiciária de

\footnotetext{
${ }^{96}$ Mais tarde conforme um aviso de 9 de Setembro de 1830 expedido à Junta para que informasse sobre o requerimento de Francisco Lúcio Duarte Reis, segundo o qual teria sido apresentado e solicitado a esta última um pedido para aí continuar a advogar, atendendo a que não havia sido renomeado, nos termos do assento da Junta de 23 de Agosto 1830 e que aplicava o disposto no Decreto de 27 de Junho de 1830, do Alvará de 10 de Setembro de 1811 e do Decreto de 2 de Junho de 1830 que fixavam o número de advogados habilitados a exercer funções junto desta entidade. Na resposta, a Junta invocaria que o Suplicante não preenchia os requisitos consagrados nas OF 1.40.2, pelo que não havia lugar à legitimidade do pedido.

${ }^{97}$ Cfr. fls. 29 e $56 \mathrm{v}$.
} 
Mouzinho da Silveira, isto é, do governo vitorioso de D. Pedro. Esta reforma seria complementada pelo Decreto n. ${ }^{\circ}$ 65, de 28 de Junho de 1833 que dividia o Reino em quatro distritos judiciais que tinham por sede Lisboa, Porto, Lamego e Castelo Branco que correspondiam, por seu turno, às províncias da Estremadura, Além-Tejo e Algarve, Minho e Douro, Trás-os-Montes e Beira Alta e, por fim, Beira Baixa (art. $40^{\circ}$ ). A estes textos legais se associaria o Decreto . $^{\circ}$ 27, de 19 de Maio do ano seguinte assim como vários diplomas legislativos de Abril-Maio, Junho e Dezembro de 1833 que lhe assegurariam a execução prática.

Uma palavra em especial para o Decreto . $^{\circ} 24$ que ao separar rigorosamente a Justiça da Administração dividia judicialmente o reino em círculos judiciais, comarcas, julgados e freguesias $\left(\operatorname{art.} 17^{\circ}\right)$. Em cada uma das vilas que compunham o círculo judicial e que eram simultaneamente cabeça de julgado, e que, até então, haviam sido assistidas por um juiz de fora, figurava agora um juiz ordinário com autoridade em todo o julgado, assim como dois escrivães e dois oficiais de diligências (art. $8^{\circ}$ ). Seguia-se-lhe, nas freguesias, um juiz de paz e um escrivão (art. $10^{\circ}$ ).

Extinta a Junta Suprema de Justiça de Angra, seria instituída a Relação de Ponta Delgada, por determinação do disposto dos arts. $2^{\circ} \S 1$ e $6^{\circ}$ do já mencionado Decreto n. ${ }^{\circ} 24$, de 16 de Maio de 1832.

A legislação de Mouzinho introduziria um tribunal de segunda instância nos Açores, circunscrição geográfica que agora formava um distrito judicial, nos termos dos arts. $2^{\circ} \S 1$ e $6^{\circ}$, com sede em Ponta Delgada ${ }^{98}$, ao qual o diploma de 25 de Maio de 1833 atribuía a designação de Relação dos Açores (art. $1^{\circ}$ ). Ao longo do séc. XIX várias vezes seria proposta a sua extinção, até porque o provimento de magistrados que aí era efectuado era visto por estes como uma penalização no cursus honorum.

Aliás, não deixa de ser interessante frisar que os magistrados que haviam desempenhado funções na Junta de Justiça não foram valorizados por isso, não lhes valendo aquele período como determinante para a nomeação para a Relação de Lisboa, ou mesmo o Supremo Tribunal de Justiça.

\section{Conclusão}

Por isso, a construção levantada por Mouzinho da Silveira oscilou por vinte anos, sem alicerces, batida pelo vento das revoluções, desconjuntando-se no seio de uma anarquia, ameaçada a toda a hora de uma ruína eminente ${ }^{99}$.

A Junta de Justiça ao suceder à Relação de Angra criada em 1829, apresentou-se como um tribunal ad hoc, sem que o estatuto de tribunal especial ou revolucionário

\footnotetext{
${ }^{98}$ Mais tarde, o Decreto de 2 de Abril de 1833, transferiria a sede deste mesmo tribunal de Ponta Delgada para Angra.

${ }^{99}$ In Oliveira Martins, op. cit., p. 283.
} 
lhe possa ser imputado. A sua competência exorbita a de um mero órgão jurisdicional de segunda instância, desde logo pela assumpção de atribuições que até então eram da competência do Desembargo do Paço e, que, mais tarde, serão parcialmente conferidas ao STJ.

Ainda que a área de jurisdição e as matérias que foram conhecidas não permitam autonomizar em termos de importância este tribunal, entendemos que como em tantas outras situações verificadas no plano judiciário oitocentista, a solução encontrada através da criação da Junta de Justiça não só se apresenta como um órgão que pretende apresentar uma solução para um problema imediato de gestão da justiça mas também espelha a tentativa de adaptação e adequação a um novo quadro que se pretendia instituir, reflectindo de modo inequívoco a fragilidade das instituições judiciárias então criadas. 